
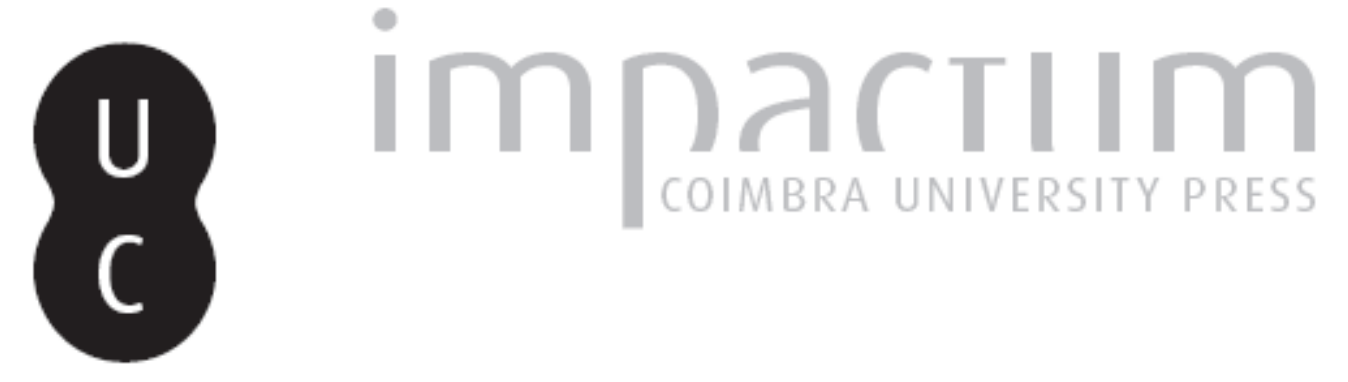

El Ars praedicandi de Alfonso de Alprão: introducción y traducción
Autor(es): $\quad$ Pulido, Manuel Lázaro; Álvarez Alonso, José Félix
Publicado por: Faculdade de Letras da Universidade de Coimbra, Instituto de Estudos Filosóficos

URL

persistente:

URI:http://hdl.handle.net/10316.2/33434

DOI:

DOI:http://dx.doi.org/10.14195/0872-0851_43_8

Accessed : $\quad$ 26-Apr-2023 09:45:48

A navegação consulta e descarregamento dos títulos inseridos nas Bibliotecas Digitais UC Digitalis, UC Pombalina e UC Impactum, pressupõem a aceitação plena e sem reservas dos Termos e Condições de Uso destas Bibliotecas Digitais, disponíveis em https://digitalis.uc.pt/pt-pt/termos.

Conforme exposto nos referidos Termos e Condições de Uso, o descarregamento de títulos de acesso restrito requer uma licença válida de autorização devendo o utilizador aceder ao(s) documento(s) a partir de um endereço de IP da instituição detentora da supramencionada licença.

Ao utilizador é apenas permitido o descarregamento para uso pessoal, pelo que o emprego do(s) título(s) descarregado(s) para outro fim, designadamente comercial, carece de autorização do respetivo autor ou editor da obra.

Na medida em que todas as obras da UC Digitalis se encontram protegidas pelo Código do Direito de Autor e Direitos Conexos e demais legislação aplicável, toda a cópia, parcial ou total, deste documento, nos casos em que é legalmente admitida, deverá conter ou fazer-se acompanhar por este aviso. 


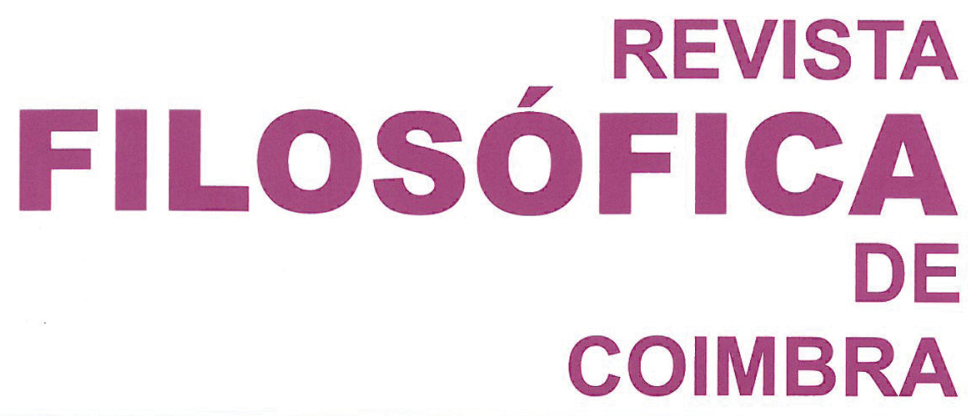

vol. 22 - número 43 - março 2013

vol. 22 - número 43 - março 2013

Fundação Eng. António de Almeida

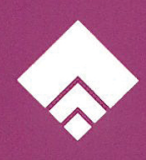




\title{
EL ARS PRAEDICANDI DE ALFONSO DE ALPRÃO INTRODUCCIÓN Y TRADUCCIÓN (1)*
}

\author{
MANUEL LÁZARO PULIDO** \\ JOSÉ FÉLIX ÁLVAREZ ALONSO****
}

Resumen: Presentamos la traducción del opúsculo Ars praedicandi del franciscano Alfonso de Alprão a partir de la edición de Albert G. Hauf. La traducción viene precedida de una introducción en la que presentamos el contexto literario (artes poetriae y dictaminis) en el que se expresa el pensamiento parenético franciscano.

Palabras clave: Ars praedicandi, Alfonso de Alprão, Retórica, filosofía medieval y escolástica

Abstract: We present the Spanish translation of the Franciscan Alfonso de Alprão's opuscule titled Ars praedicandi, from the edition of Albert G. Hauf. The translation is preceded from an introduction focused in the literary context (artes poetriae and dictaminis) that expresses the parenetic, Franciscan thought

Key-words: Ars praedicandi, Alfonso de Alprão, Rhetoric, medieval philosophy and scholasticism

*Actividade do Projecto de Investigação, Imago mundi - Filosofia medieval em texto e tradução 1 (IM.FMTT-1) Imago mundi - Medieval Philosophy in Text and Translation (IM.MPTT-1) (PTDC/FIL-FIL/098044/2008).

** Investigador do Gabinete de Filosofia Medieval / Instituto de Filosofia da Universidade do Porto (C2008, co-financiado pelo FSE e pelo POPH). Actividade do Projecto de Investigação, Imago mundi - Filosofia medieval em texto e tradução 1 (IM.FMTT-1) Imago mundi - Medieval Philosophy in Text and Translation (IM.MPTT-1) (PTDC/FIL-FIL/098044/2008).

*** Profesor de Latín del Instituto Teológico de Cáceres, Centro afiliado a la Facultad de Teología de la Universidad Pontificia de Salamanca. 


\section{Introducción: algunas notas contextuales al Ars praedicandi de Alfonso de Alprão}

1. "Magistro Alphonsus d'Alpran, Ordinis Fratrum Minorum, provintiae Sancti Iacobi", es el explicit del opúsculo Ars praedicandi. El texto sitúa a un autor de quien no sabemos mucho. Alfonso de Alprão escribe el Ars praedicandi siendo bachiller de teología en Bolonia en el año 1397 y desarrolla su actividad pastoral como vicario del ministro general (1407); sabemos que fue comisionado de Juan XXII, en 1412, para dar el grado de maestro a fray Alfonso de Buenaventura, año en el que también llegará a ser ministro provincial de la provincia de Santiago, si bien parece ser que no tuvo jurisdicción sobre los frailes de Galicia. Franciscano, escolástico, estudiante en Bolonia, son tres elementos que deberemos tener en cuenta ${ }^{1}$.

Presentamos la traducción de un texto que puso a la luz de una forma impagable Albert G. Hauf, quien fijó la edición del opúsculo Ars praedicandi de Alfonso de Alprão (Alphonsus de Alpram, Alfonso de Alporão) ( $\dagger$ 1422) a partir de dos manuscritos presentados por Thomas-Marie Charland y Harry Caplan: Oxford Bodleian Library Ms. Hamilton 44 (Tractatus de modo predicandi) y el Cracovia Universytet Jagiellonska Ms. 471 Aaa 1.8 ("Incipit ars predicandi, collationandi, harengandi...")2. La introducción que realiza el profesor A. G. Hauf en la que va siguiendo el contenido del texto en comparación con el doctor (Francesc) Eixeminis (ca. 1330-1409) y Fr. Martín Alfonso de Córdoba († 1476), pone en evidencia, por una parte, la importancia de la profundización en estos estudios, como el propio autor señala al recordar las palabras de A. Deyermond que reproducimos, en la cita expuesta por A. G: Hauf: "Un aspecto descuidado por la crítica es el de la difusión de los sermones y artes praedicandi en

${ }^{1}$ M. Castro, La provincia franciscana de Santiago. Ocho siglos de historia, ed. Monte Casino, Santiago de Compostela 1984. Cf. A. López, "Ministros provinciales de Santiago en el siglo XV", en Archivo Iberoamericano 6 (1916) 354; F. Félix, "Franciscanos portugueses pretridentinos escritores, Mestres e leitores", en Repertorio de historia de las ciencias eclesiásticas en España 7 (1979) 451-505.

${ }^{2}$ A. G. Hauf, "El «Ars Praedicandi» de Alfonso d'Alprão, O.F.M. Aportación al estudio de la teoría de la predicación en la Península Ibérica”, en Archivum Franciscanum Historicum 72 (1979) 233-329. El estudio introductorio: 233-261; "Códices y advertencias sobre la edición”: 262-263; edición del opúsculo: 264-329. Th.-M. Charland, Artes praedicandi. Contribution a l'histoire de la rhétorique au Moyen Âge, Institut d'Études Médiévales, Ottawa 1936, p. 25; H. Caplan, Mediaeval artes praedicandi. A Hand-list, Cornell University Press, Ithaca 1934, n. 44; Mediaeval artes praedicandi. A Supplementary Hand-list, Cornell University Press, Ithaca 1936, n. 72. 
la España medieval"1; y, por otra parte, que el opúsculo de Alfonso de Alprão resulta paradigmático en el intento de realización de un manual "ejemplar" de sermón en los dos sentidos de la palabra "ejemplar": de un lado, se trata de un manual escolástico y paradigmático de la utilización de la técnica, en la que combina teoría y ejemplificación; y, de otro lado, en el sentido que da al uso de los exempla en la formación del sermón ${ }^{2}$.

Sugerimos desde el inicio tener siempre presente el trabajo de Hauf, tanto su introducción como la edición que realiza del opúsculo del que presentamos su traducción en español. La introducción del editor presenta un profundo estudio temático del desarrollo del manual de predicación del Fr. Alfonso que no debe ser repetido porque es completo y no merece empobrecerlo. Por otra parte, la edición crítica sugiere un aparato crítico que merece ser retenido. No obstante, presentamos una breve introducción, sencilla y de carácter más general, pensada para lectores no especialistas, fundamentalmente venidos de la filosofía que, aun siendo medievalistas, no han tenido la ocasión de acercarse a este tipo de escritos medievales y renacentistas. Terminamos la introducción con un apunte sobre la propia traducción, una introducción realizada por el profesor José Félix Álvarez Alonso. En este trabajo en equipo, ha sido él, como latinista, el encargado de llevar el peso fundamental de la traducción, que hemos revisado entre los dos por las características propias de la obra. Creo que se puede convenir que en este tipo de literatura el trabajo interdisciplinar es indispensable, tratando siempre de sumar competencias y ponerlas al servicio del bien común, en este caso la traducción de una obra que sea lo más útil posible y que pueda estar disponible para los filósofos, pero que por su naturaleza pueda ser provechosa a historiadores, a pedagogos (pues se trata de un manual de interés en los estudios de historia de la educación), especialistas en literatura y filología, así como aquellos interesados en conocer un poco más el patrimonio cultural de la Península Ibérica y la impagable contribución en esta época de las Órdenes mendicantes a la cultura occidental. Un instrumento, en fin, propuesto tanto a profesores como a estudiantes.

La temática de las artes de la predicación, que tiene un componente eminentemente apegado a la disciplina literaria, hay que contextualizarla, sin embargo, en los estudios medievales (y renacentistas); y, desde ahí, no se puede ser ajeno a los estudios de historia de la filosofía en el periodo medieval, en cuanto práctica que se entronca con la difusión de

${ }^{1}$ A. Deyermond, Historia de la literatura española: la Edad Media, $3^{\mathrm{a}}$ ed., E. Ariel, Barcelona - Caracas - México 1976, 114, n. 15, edición citada en A. G. Hauf, "El «Ars Praedicandi»»", cit., 233.

2 Cf. A. G. Hauf, "El «Ars Praedicandi»", cit., 261. 
los topoi del pensamiento filosófico y teológico del sermón. Por poner un paralelismo que puede no ser afortunado, pero, quizás, sí ilustrativo (compensando así la falta de rigor), se trataría de estudiar en el terreno de la filosofía el papel de la retórica actual de los mass media, de los medios de comunicación, en los diferentes terrenos y contextos de comunicación, toda vez que el sermón (y la técnica sermocinal) en general -en sus diversas vertientes y contextos (populares, pastorales, académicos)- $y$, particularmente, la predicación, constituyen una fuente importantísima de divulgación de contenidos en la vivencia de las poblaciones en la época medieval y renacentista. Especialmente significativa en esta tarea se situaba la predicación, entendida como un "acto de comunicação social - e é-o em funçao do destinatário"1; una actividad que va creciendo poco a poco de la mano de la retórica, que va adquiriendo un empuje propio y que tiene su reflejo en una "disseminação crescente" como señalan Corrêa de Oliveira y Saavedra Machado en su estudio sobre los textos medievales portugueses ${ }^{2}$. De esta forma, la predicación se inserta, como arte de la palabra, dentro del discurso retórico, y como todo recurso retórico era enseñado en un ambiente escolar determinado. Más aun, se va constituyendo y desarrollando como forma del arte de la palabra, arte que fue determinándose en diversos recursos didácticos, patrones ejemplares destinados al aprendizaje y a la resolución paradigmática de modelos de utilización, en las diversas vertientes prácticas del uso de dicha palabra y escritura. Y, por lo tanto, difundiéndose en las varias artes de las que el Arte de predicar es una de ellas, configurando un corpus retórico que se va creando en la Edad Media y vertiéndose en los diversos ambientes y lugares geográficos, comprendida, evidentemente, la Península Ibérica, donde el género adquirirá, con el desarrollo de la retórica, especialmente eclesiástica, un alto nivel, de forma especial a partir del desarrollo del estudio de la retórica en los studia humanitatis del Renacimiento ${ }^{3}$. El

${ }^{1}$ J. Francisco Marques, "Introdução- Fontes e métodos. 1. Delimitação do corpus da Parenética Portuguesa da Restauração: fundamentação histórica”, en A parenética Portuguesa e a Restauração, Vol. 1, Instituto Nacional de Investigação Científica - Centro de História da Universidade do Porto, Porto 1989, p. 8

2 Textos Portugueses Medievais, 2a ed., Atlántida-Livraria Editora, Coimbra 1961, p. 667.

${ }^{3} \mathrm{Al}$ respecto podemos señalar algunas obras referentes a la retórica de los siglos XV y XVI, estudios que algunas veces se centran más en los retóricos que en la propia arte retórica. Interesante resulta la obra general de Karl Kohut, Las teorías literarias en España y Portugal durante los siglos XV y XVI. Estado de la investigación y problemática, CSIC, Madrid 1973, a las que se le pueden añadir algunos interesantes estudios y obras. Cf. A. Martí, La preceptiva retórica española en el siglo de Oro, Gredos, Madrid 1972; J. Rico, La Retórica española de los siglos XVI y XVII, CSIC, Madrid 1973; A. Pinto de Castro, 
Siglo de Oro y la retórica sermocinal del Barroco serán reflejo brillante de este recorrido.

2. Conviene recordar brevemente algunos conceptos generales que están detrás del método de predicación (el arte de predicación) -que es el objeto de la traducción que presentamos-y el contexto más general, especialmente para los lectores más apegados a la formación filosófica. La retórica, recordemos, es una técnica en la que se construye el discurso, especialmente el discurso oral ${ }^{1}$. Siendo el medio utilizado para la comunicación de un contenido el discurso oral, fija su atención en las circunstancias y contextos del auditorio receptor del mensaje oral. De esta forma, la técnica ha de servir al orador para adecuar su discurso a una situación de comunicación concreta, que depende del contenido, el medio, el lugar y el receptor del discurso, en fin, de las realidades presentes en el fenómeno del discurso oral. En este sentido, el discurso oral puede reglarse, pero siempre se mueve en un contexto más dinámico y cambiante. Más inseguro en la seguridad de lo que se quiere decir, fija su atención en la transmisión del contenido. La retórica domina así el escenario emotivo. La gramática, por su parte, es una técnica utilizada para la construcción correcta de un discurso, especialmente un texto. Siendo el texto algo que se fija por escrito cabe en él mayor posibilidad de establecer reglas más determinadas que en la retórica. El texto puede ser estructurado en partes, puede construirse de forma organizada, con un esquema predefinido y fijado tras un análisis de las partes y la conjunción de las mismas. Domina la estabilidad en la transmisión del discurso, la seguridad del contenido se impone a la comunicación del mismo. La gramática domina el espacio racional. Ambas, retórica y gramática, siendo diferentes y apuntando a situaciones sistémicas divergentes, sin embargo, pueden compaginarse. El discurso hablado, sujeto de la oratoria, se apoya muchas veces en textos, de manera que la habilidad a la hora de ejercer el arte retórico de pronunciar oralmente un discurso puede apoyarse en el arte de construir un texto de forma correcta y adecuada utilizando las artes y recursos gramaticales. Esta generalización tiene sus momentos de desarrollo histórico, que con la llegada del cristianismo, implica la construcción de un nuevo

Retórica e teorização literária em Portugal do humanismo ao neoclassicismo, Centro de Estudos Românicos, Coimbra 1973; A. García Berrio, Formación de la teoría literaria moderna. 2 vols. Cupsa, Madrid 1977 y Editum, Murcia 1980; L. López, La Retórica en la España del Siglo de Oro, $2^{\mathrm{a}}$ Ed., Ediciones Universidad de Salamanca, Salamanca 1995. B. F. Pereira, "Des arts de prêcher à la rhétorique sacrée: la prédication au Portugal pendant la Renaissance”, Ágora. Estudos Clássicos em Debate 10 (2008) 81-96.

${ }^{1}$ Cf. H. Lausberg, Manual de Retórica Literaria, Gredos, Madrid 1983. 
paradigma nacido de la práctica pastoral y bajo el influjo en la estructura de contenido gramatical, en el contexto ciceroniano, de la obra de san Agustín (354-430), especialmente el De doctrina christiana. Hemos de tener en cuenta este background a la hora de acercarnos a la lectura del Ars preadicandi de Alfonso de Alprão.

Diversos estudios han fijado su atención en la lectura medieval de las artes de la retórica y la gramática a partir de la creación (o recreación) de las artes específicas ${ }^{1}$. Existen una variedad de tipos de artes. James J. Murphy insiste en señalar de forma específica, entre las que existen, tres formas de construcción del arte de la retórica (en la gramática Elio Donato, s. IV, construye el Ars grammatica ${ }^{2}$ ). Corresponden a tres géneros retóricos, a saber, el Ars praedicandi, el Ars dictaminis (o dictandi), y el Ars poetriae ${ }^{3}$. De estos tres géneros nos interesa el último, pero debemos al menos señalar algunas palabras sobre los otros dos, toda vez que son en cierta forma concomitantes, especialmente en lo que se refiere al segundo (Ars dictaminis o Ars dictandi), arte al que el autor de la obra que presentamos hace referencia explícita al hablar del tema: "Hoc intendit dicere Strattioloton, qui definit thema dicens : "Thema est materia dictatorum, id est materiale fundamentum dictatoris». Et dictatos sumitur hic pro oratore" (Ars Praedicandi, I.I), reflejo de la importancia que estos géneros fueron adquiriendo en la Edad Media, en una muestra de lo que John O. Word señala como un "apogeo del movimiento retórico" 4 en esta época. Recordemos que, en general, estas artes son tratados de tipo teórico-prácticos en los que se dispone una instrucción para la constitución de diversos trabajos de composición de diversas tipologías de

${ }^{1}$ Cf. P. O. Kristeller, "La Retórica en la Cultura Medieval y Renacentista", en J. J. Murphy, (ed.), La elocuencia en el Renacimiento, Visor, Madrid 1999, pp. 11-31.

2 Elio Donato, Ars grammatica maior, ed. A. M. Negri, Tip. Guidetti, Reggio Emilia 1960; L. Holtz (ed.), Donat et la tradition de l'enseignement grammatical. Etude sur l'Ars de Donat et sa diffusion (IV e-IX e siècle) et édition critique, CNRS, Paris 1981.

${ }^{3}$ J. J. Murphy, Rhetoric in the Middle Ages: a history of rhetorical theory from Saint Augustine to the Renaissance, University of California Press, Berkeley - Los Ángeles London 1981, pp. 135-355 (ed. en español: La retórica en la Edad Media: Historia de la retórica desde San Agustín hasta el Renacimiento, F.C.E., México 1986). El mismo autor desarrolla estos tres géneros presentando tres tratados medievales que van de 1135 a 1322 en Id. (ed.), Three Medieval Rhetorical Arts, University of California Press, Berkeley 1985. Sobre la retórica medieval entre otros R. McKeon, "Rhetoric in the Middle Ages", en Speculum 17 (1942) 1-32.

${ }^{4}$ J. O. Ward, "From Antiquity to the Renaissance: Glosses and Commentaires on Cicero's Rhetorica", en J. J. Murphy (ed.), Medieval eloquence: studies in the theory and practice of medieval rhetoric, University of California Press, Berkeley 1978, p. 45. 
escritos $^{1}$. El valioso trabajo del profesor y especialista en las artes retóricas y de forma especial de las penitenciales, Antonio Alberte, ha puesto en evidencia, desde la retórica, la importancia de las artes predicatorias ${ }^{2}$, señalando no solo sus tradiciones retóricas clásicas y escolásticas, sino recordando la necesidad de no olvidar "otras fuentes cuya influencia ha sido igualmente importante: es el caso de las Artes dictaminum y Artes poetriae" 3 . Afirmación subrayada también por Pedro Martín Baños, y que aquilata lo que aquí se quiere señalar y la propia lectura de nuestro opúsculo, cuando escribe:

"Sería interesante explorar, por ejemplo, las conexiones entre la doctrina del dictamen y los comentarios a las retóricas ciceronianas, y también entre las artes dictaminis y las artes poetriae y artes praedicandi. Las artes poetriae estudian, dentro de su doctrina del ordo artificialis, varios modos de comenzar una composición, entre los que se encuentran el proverbium y el exemplum. Las artes praedicandi, por su parte, conciben el sermón como el desarrollo de un thema general. El predicador, además, se sirve en su labor creativa de colecciones de exempla, que también está presentes, frecuentemente en las artes dictaminis"4.

3. Los tratados de Ars poetriae aparecen tras la evolución de la gramática estudiada en el trivium. Se tratan de unos tratados de las artes de composición de textos que constituyen una especie de guía a partir de cuestiones de carácter teórico (disposición, fórmulas...) y estilísticas (decorum y ornatos) para componer prosa y poesía ${ }^{5}$. Algunos tratados medievales como el Ars versificatoria (ca. 1175) de Mateo de Vendôme (ca. 1095-1185) o la Poetria Nova (1208-1213), el Documentum de modo et arte dictandi et versificandi, la Summa de coloribus rhetoricis de Godofredo de Vinsauf (ca. 1200) traídos por Douglas Kelly6 , así como la Ars

${ }^{1}$ Cf. Marianne G. Briscoe sigue la Rhetorica ad Hernnium, M. G. Briscoe, - B. H. Jaye, Artes praedicandi. Artes orandi, Brepols, Turnhout 1992, p. 17.

2 Cf. A. Alberte, Retórica medieval: historia de las artes predicatorias, Centro de Lingüística aplicada atenea, Madrid 2003.

${ }^{3}$ A. Alberte, "Las «Artes Dictaminum» y «Poéticas Medievales» en las artes predicatorias”, en V. Valcárcel - C. Pérez (eds.), Poesía medieval (Historia literaria y transmisión de textos), Fundación Instituto Catellano y Leonés de la Lengua, Burgos 2005, pp. 461-483.

${ }^{4}$ P. Martín, El arte epistolar en el Renacimiento europeo 1400-1600, Universidad de Deusto, Bilbao 2009, pp. 156-157.

${ }^{5}$ El gran tratado de este arte es E. Faral, Les arts poétiques du XII et du XIII ${ }^{e}$ siècles. Recherches et documents sur la technique littéraire du Moyen Age, É. Champion, Paris 1924 (rep. 1958, 1962). W. M. Purcell, Ars poetriae: rhetorical and grammatical invention at the margin of literacy, University of South Carolina Press, Columbia 1996.

${ }^{6}$ Cf. D. Kelly, The Art of Poetry and Prose, Brepols, Turnhout 1991. Esta obra entendida como una guía de trabajo ofrece una bibliografía adecuada desde el estudio de E. 
versificaria (ca. 1215) de Gervasio de Merkley (XII-XIII), se componen acompañando a las obras antiguas. Según el propio Murphy, el movimiento abarca el periodo que va entre el primero y el último de los autores, declinando a partir de la Poetria de Juan de Garlandia (ca. 1180-1252) y especialmente con Everardo el Alemán (s. XIII) (Laborintius) ${ }^{1}$.

A pesar de la duración específica de estos manuales medievales, se dejó sentir su huella. Así sabemos de su lectura e inspiración en España, especialmente el Ars versificatoria de Mateo de Vendôme, que inspira el Breve compendium artis rhetorice, de finales del siglo XIII, de Martín de Córdoba (c. 1270-c. 1350) ${ }^{2}$ y que a la larga deja su huella en la España del siglo XV en otros manuales como los de Juan del Encina (1468-1529) ${ }^{3}$ o el Marqués de Santillana (1398-1458) ${ }^{4}$. En todo caso, está claro que a pesar de las variaciones no se pierde la vinculación con los estudios clásicos, como los manuscritos del Ars poetica de Horacio (65 a. C-8 a. C), pues como ha señalado el profesor José Luis Pérez Pastor: "La Epistula ad Pisones de Horacio, conocida ya desde antiguo como Ars poética es un texto que ha tenido una enorme fortuna como base de la teoría estética y de la preceptiva literaria de Occidente, con una continuidad más o menos estable desde la Antigüedad tardía y la Edad Media hasta llegar al Renacimiento" ". En la Castilla de los siglos XIII y XIV se usan

Faral, presentando una excepcional bibliografía general (pp. 10-36) a las que añade una lista de artes poéticos en lengua vernácula interesante (pp. 176-179). Cf. A. M. Calvo, "Los mecanismos de la expresividad en la «Poetria nova» de Godofredo de Vinsauf", Universidad Autónoma de Madrid, Madrid 2000, en esta obra que refleja el trabajo de una tesis doctoral se pueden observar los entresijos de este arte. Traducción al español en C. Ponce, Geoffroi de Vinsauf. La Poética Nueva, Universidad Nacional Autónoma de México, México 2000.

${ }^{1}$ J. J. Murphy, Three Medieval, cit., pp. 170-171. Cf. J. L. Martos, "Eberardo el Alemán y la crisis poética", en Revista de poética medieval 11 (2003) 41-52.

2 T. Jiménez, "El prefacio del Breve Compendium Artis Rhetorice de Martín de Córdoba. Edición, traducción y comento", en Revista de Poética Medieval 2 (1998) 226-44.

3 Juan del Encina, Arte de Poesía, ed. y est. en J. C. Temprano, "El Arte de la poesía castellana de Juan del Encina. Estudio y edición”, en Boletín de la Real Academia Española 53 (1973) 9-5; edición en Obras Completas, vol. I, ed. Ma Rambaldo, Espasa Calpe, I, Madrid 1978, pp. 6-29. También en Las Poéticas castellanas de la Edad Media, ed., est. preliminar y not. F. López, Taurus, Madrid 1985, pp. 77- 93.

${ }^{4}$ Marqués de Santillana, Proemios y Cartas Literarias, ed. M. Garci-Gómez, Editora Nacional, Madrid 1984; Proemio (Proemio e Carta del Marqués de Santillana al Condestable de Portugal), en Las Poéticas castellanas, cit., pp. 51-63.

5 J. L. Pérez, "La traducción del licenciado Francisco de Cascales del Ars Poetica de Horacio", en Criticón 86 (2002) 21. Sobre la transmisión del texto cf. B. Weimberg, A History of Literary Criticism in the Italian Renaissance, 2 vols., University of Chicago Press, Chicago 1961. 
traducciones latinas de la Rhetorica de Aristóteles, el De inventione de Cicerón y la Rhetorica ad C. Herennium. Alfonso de Cartagena, en el siglo XV, traduce el De inventione de Cicerón (Rethórica de M. Tullio Cicerón, h. 1420) ${ }^{1}$.

Vertida al castellano, la obra Poetria nova de Godofredo de Vinsauf, muestra la lectura y elaboración tradicional de las reglas de la composición de la poesía en la Edad Media, a través de la utilización de los esquemas de la retórica tradicional. Como señala el editor del libro, en esta obra nos encontramos con el fruto de la combinación de la tradición gramatical de la enarratio poetarum con los preceptos sobre la composición derivados de la retórica de acuerdo con los principios estéticos del momento ${ }^{2}$. Y es que la suerte de las distintas artes poéticas tienen su propio recorrido dependiendo del autor, y, sin duda, se relacionan con las artes concomitantes como el Ars grammaticae y el Ars rhetoricae, toda vez que la poética, cuyo elemento fundamental se centra en el verso, como define Mateo de Vendôme en su Ars versificatoria ${ }^{3}$, se trata dentro de la gramática en las enseñanzas de las artes. De hecho, el Ars poetriae es una subdivisión del Ars grammatica que sintetiza los elementos de la retórica y la gramática suficientes para la composición de la prosa y la poesía.

Por otra parte, la poética también tiende a confluir con la retórica ${ }^{4}$. Así que siendo diferentes, ya desde la época romana, la concurrencia se da de una forma significativa, incluso llegando a una confusión, algo que, como señala Roland Barthes, llega a implicar una variación en la propia significación de la retórica. La implicación filosófica de la retórica descrita y propuesta por Aristóteles, a través de las distinciones en los discursos (judicial, deliberativo y demostrativo) y marcados por el proceso lógico-dialéctico (inventio, dispositio, elocutio y actio), va variando, en gran parte modificados por la confusión poético-literaria, por medio de la modificación de la carga de la prueba, especialmente en la elocutio: la composición del estilo lógico y argumental varía en la composición estilística y de composición literaria ${ }^{5}$. De razonar bien se pasa a escribir bien.

\footnotetext{
${ }^{1}$ Ch. Faulhaber, "Retóricas clásicas y medievales en bibliotecas castellanas", en Ábaco 4 (1973) 158-159.

2 Godofredo de Vinsauf, Poetria nova, trad. A. Calvo, Arco Libros, Madrid 2009.

3 "Versus est metrica oratio succincte et clausulatim progrediens venusto verborum matrimonio et flosculis sententiarumf picturata, quae nihil diminutum, nihil in se continet otiosum". Mathieu de Vendôme, Ars versificatoria, I, 1, ed. F. Munari, (Matteo di Vendôme, Ars Versificatoria 1 - 111”, en Studi Medievali Firenze 1 (1976) 293-305).

${ }^{4}$ Cf. W. M. Purcell, "Ars poetriae": Rhetorical and Grammatical Invention at the Margin of Literacy, University of South Carolina Press, Columbia 1996.

${ }^{5}$ R. Barthes, "L'ancienne rhétorique : aide-mémoire", en Communications 16 (1970) 177-229 (versión española: La antigua retórica. Ayudamemoria, Ed. Buenos Aires, Barce-
} 
4. Junto al arte de la poética destaca significativamente las Artes dictaminis o Artes dictandi. Se trata de un arte típicamente medieval que rompe con la práctica de la retórica anterior, que se podía manifestar en el arte poética ${ }^{1}$, y que desarrolla la composición de textos en prosa. Mientras que en la actividad prosística clásica la composición de cartas es un género que rara y tardíamente aparece en una dimensión de carácter significativo, en la Edad Media va a ocupar un lugar importante, con el desarrollo de una técnica en la que se configuran unos modelos fijados, insistiendo, especialmente, en las normas precisas para escribir cartas (dictamen), tratándose de cartas especialmente tratadas en el mundo de la administración y el derecho, tanto en las cancillerías laicas como en la papal ${ }^{2}$.

La actividad de dictar (dictare) era realizada por el dictator, el maestro de este arte de dictar, quien se encargaba de forma oficial de escribir y componer (puesto que el dictare era tomado en el sentido de componer) las cartas (dictatos). Y, precisamente, para poder realizar de forma más fácil esta tarea se redactaron los Ars dictaminis o Ars dictandi. Con el tiempo, estos manuales o tratados van ganando en riqueza teórica apegada a la retórica, tanto en su estructuración (la unión más conjuntada de sus diversas secciones), como en sus formas estilísticas (relativas a la riqueza ornamental de las formas retóricas empleadas), siendo entendidas

lona 1982). "la narratio está concebida únicamente desde el punto de vista de la prueba, es la exposición persuasiva de algo que se ha hecho o se pretende que se ha hecho. La narración no es pues un relato (en el sentido novelesco o como desinteresado del término) sino una prótasis argumentativa. En consecuencia presenta dos caracteres obligados: su desnudez... y su funcionalidad" (p. 69).

${ }^{1}$ J. J. Murphy, Rhetoric in the Middle Ages, cit., p. 194: "The ars dictaminis is a truly medieval invention. It marks a Sharp break with ancient rhetorical practice". Sobre la presencia "oblicua" del ars dictaminis en la antigüedad tardía, especialmente en san Agustín y su influencia cf. L. Leoncini, "La «concinnitas» nella prosa di Dante. Da Cicerone ad Agostino, al di là (e al di qua) dell' «Ars dictaminis»”, en Aevum 81 (2007) 523-557.

2 M. Camargo (Ars Dictaminis, Ars Dictandi, Brepols, Turnhout, 1991, p. 17) señala y define muy bien este arte: "Dictamen, from the verb dictare in its generalized meaning for "to compose", was used during the Middle Ages to designate any type of composition. As part of the term ars dictaminis, however, its reference was restricted to prose composition. The medieval dictatores, or teachers of the ars dictaminis frequently began their artes dictandi, in fact, by distinguishing among the various types of dictamen. They always specified at least dictamen prosaicum and metricum, more often adding rythmicum as a third type, and occasionally prosimetricum as a fourth. Having excluded the other types of composition, the dictatores frequently went on to subdivide dictamen prosaicum into its various subspecies, from which epistola was then selected as the particular concern of the ars dictaminis". 
como una unidad que precisa tener en cuenta y guardar una normativa estilística precisa y una formación en las que las partes se definen y se suceden: siguiendo las partes expresadas en la oración ciceroniana que se habían fijado en cinco: salutatio, exordium (o captatio benevolentiae y proverbium), narratio, petitio y conclusio $^{1}$.

Italia $^{2}$ y Francia son dos focos fundamentales en la composición de estos tratados ${ }^{3}$ que irán extendiéndose a otros lugares como Inglaterra ${ }^{4}$. Tal como señala James J. Murphy, es en Montecassino, en el siglo XI, donde se escribe los Flores rhetorici $i^{5}$ que representa un primer ensayo de ars dictandi. Estos modelos sencillos en los que se enseña el arte epistolar, tornados en manuales van extendiéndose y aparecen tratados de significativa importancia en los siglos posteriores. En el norte de Italia, especialmente en Bolonia, florecen obras significativas de este arte en torno a las Rationes dictandi y las disputas estilísticas existentes entre Hugo de Bolonia y Adalberto Samaritano (disputas habidas entre 1115-1124), o lo que es lo mismo, entre una forma religiosa y otra secular de composición y contextualización, reflejo de la importancia de la retórica en el curriculum escolar que se está confirmando en esta época singular de creación del método escolástico ${ }^{6}$. Así, se pueden señalar las del maes-

${ }^{1}$ Ibid., p. 22. Cf. J. J. Murphy, Rhetoric in the Middle Ages, cit., pp. 221-225. Los distintos esquemas formales y estructuras del siglo XII aparecen brevemente en F. J. Worstbrock - M. Klaes - J. Lütten (eds.), Repertorium der Artes dictandi des Mittelalters, vol. 1, Wilhelm Fink Verlag, München 1992, pp. 181-182.

${ }^{2}$ Cf. G. C. Alessio, 'L'«ars dictaminis» nelle scuole dell'Italia meridionale (secoli XI-XIII)", en L. Gargan - O. Limone (eds.), Luoghi e metodi di insegnamento nell'Italia medioevale (secoli XII-XIV). Atti del Convegno internazionale di studi, (Lecce - Otranto, 6-8 ottobre 1986), Congedo, Galatina 1986, pp. 291-308.

${ }^{3}$ Para una geografía y cronología de las artes dictaminis ver: F. J. Worstbrock - M. Klaes - J. Lütten (eds.), Repertorium, cit., p. 183.

${ }^{4}$ Cf. M. Camargo (ed.), Medieval Rhetoric of Prose Composition: Five English "Artes Dictandi" and their Tradition, Center for Medieval and Early Renaissance Studies, Binghamton 1995.

5 J. J. Murphy, Rhetoric in the Middle Ages, cit., p. 203. Alberici Casinensis Flores rhetorici, ed. D. M. Inguanez - H. M. Willard, Arti grafiche e fotomeccaniche Sansaini, Montecassino, Roma 1938. Cf. "Alberic of Monte Cassino, Flowers of Rhetoric", trad. J. M. Miller, en J. M. Miller - M. H. Prosser - Th. W. Benson (eds.), Readings in Medieval Rhetoric, Bloomington, Indiana, 1973, pp. 131-161; B. Löfsted, "Notes on an English Translation of Alberici Casinensis «Flores rhetorici»", en Orpheus 18 (1997) 224-229. F. J. Worstbrock, Repertorium, o. c., pp. 9-17.

${ }^{6}$ Cf. Adalbertus Samaritanus, Praecepta dictaminum, ed F.-J. Schmale, Herman Böhlaus Nachfolger, Weimar 1961. Cf. F. J. Worstbrock - M. Klaes - J. Lütten (eds.), Repertorium, cit., pp. 1-6. Id., "Die Bologneser Shule der 'Ars dictandi'”, en Deutsches Archiv für Erforschung des Mittelalters 13 (1957) 16-34. W. D. Patt, "The Early «Ars 
tro Boncompagno da Signa (ca. 1170-ca. 1250), autor del Boncompagnus o Rhetorica antiqua (1215) y de la Rhetorica novissima (1235). Junto a estos manuales de suma importancia destaca de forma sobresaliente los de su más notorio y conocido seguidor, Guido Faba, maestro en la Universidad de Bolonia (siglo XIII), cuyas obras (Dictamina rhetorica, Summa dictaminis, Gemma purpurea, Parlamenta et epistole $)^{1}$ circulaban también en España y que introduce modelos en lengua vulgar. Juan Gil de Zamora (ca. 1241-ca. 1318) escribe en el siglo XIII un Dictaminis Epithalamium ${ }^{2}$. A Francia llega de la mano de Bernardo de Meung (s. XII), cuya Summa dictaminis será continuada por las obras de Hilaire y Foulques de Orleans ${ }^{3}$. Bolonia constituirá una importante fuente de autores especialistas en las artes retóricas y, especialmente, en las artes dictandi o dictaminis ${ }^{4}$ como puede verse en diversos autores -como Giovanni de Bonandrea $(\dagger 1321)$, un notario, que fue dictator y profesor de retórica en el estudio de Bolonia, y que escribe una notable compilación titulada Summa dictaminis $(1291)^{5}$-, asentándose la disciplina en el siglo $\mathrm{XIV}^{6}$. La presencia de este arte llega hasta el Renacimiento y se hace presente en diversos humanistas cercanos a los estudios y la enseñanza

dictaminis» as Response to a Changing Society", en Viator 9 (1978) 133-55. Hugo de Bolonia, Rationes dictandi prosaice, en L. Rockinger (ed.), Briefsteller und Formelbücher des 11. bis 14. Jahrhunderts, vol. 1, München 1863, pp. 52-94.

${ }^{1} \mathrm{Cf}$. los capítulos "Gli stili prosastici e la prosa rimata nel medioevo latino", y "L'" ars dictandi» di Guido Faba", en A. Schiaffini, Tradizione e poesia nella prosa d'arte ital. dalla latinità medievale a G. Boccaccio, $2^{\mathrm{a}}$ ed., Edizioni di Storia e letteratura, Roma 1943, pp. 9-24; 25-37.

2 Juan Gil Zamora, Dictaminis epithalamium, ed., introd. y notas de Ch. Faulhaber, Pacini Editore. Pisa 1978. Una lectura crítica dela edición en B. Löfstedt, "Zum Dictaminis Epithalamium des Juan Gil de Zamora”, en Habis 22 (1991) 383-398. Una vinculación de los sermones del fraile franciscano con la predicación puede verse en F. Lillo, "El sermonario inédito de Juan Gil de Zamora a la luz de las Artes praedicandi”, M. Pérez (ed.), Actas I Congreso Nacional de Latín medieval (León, 1-4 Diciembre 1993), Publicaciones de la Universidad, León 1995, pp. 14-38

${ }^{3}$ J. J. Murphy, Rhetoric in the Middle Ages, cit., p. 227.

${ }^{4}$ Cf. G. Vecchi, Il magistro dell "artes" latina a Bologna nel medioevo, Patron, Bologna 1958.

${ }^{5}$ Giovanni Di Bonandrea, Giovanni di Bonandrea's "ars dictaminis" treatise and the doctrine of invention in the Italian rhetorical tradition and early fourteenth centuries, ed. James R. Banker, Ann Arbor, U.M.I., Michigan 1988. Cf. M. Camargo, Ars Dictaminis, o. c., p. 49

6 J. R. Banker, "The «Ars dictaminis» and rhetorical textbooks at the Bolognese University in the fourteenth century", in Medievalia et humanistica 5 (1974) 153-163. 
de la retórica, como el caso de Juan Lorenzo Palmireno (1524-1579)1.

Como hemos señalado, Antonio Alberte ha indicado con gran acierto la influencia de estas artes en las artes predicatorias. También hemos anotado que, por ejemplo, respecto al tema, Alfonso de Alprão hace mención expresa del ars dictandi. Del estudio del profesor Antonio Alberte llama la atención la importancia referencial de la rima sobre el tema, muy presente -ahora entendemos mejor que de forma lógica- en el Ars praedicandi de Alfonso de Alprão (a ello nos referiremos, aunque brevemente después). Una vinculación que se menciona ya, hecha referencia en el Ars predicandi de Juan de Chalons (s. XIV): "Juan de Chalons observa en las Artes Dictaminum y considera trasladable a las artes predicatorias, es ampliamente tratado en éstas en el apartado dedicado a la división del tema. Estas artes formalizan la división del tema estableciendo miembros rimados, cuya función consiste en ofrecer una interpretación de los términos más significativos del tema" ${ }^{2}$.

6. Sobre la materia de las artes praedicandi contamos con obras que han definido y descrito su metodología, tanto las del ya citado James J. Murphy $^{3}$ como de Marianne G. Briscoe ${ }^{4}$, que nos sitúan en sus aspectos generales. Sin repetir lo que ya conocemos, simplemente quisiera recordar que las artes predicatorias fijan su atención en el desarrollo de una metodología adecuada en la construcción de los sermones. Si bien, el oficio de predicar es inherente a la misión evangelizadora del cristianismo, y ello supone que ya aparece en la patrística un discurso sobre la actividad sermocinal. Como señala M. G. Briscoe ${ }^{5}$, estas artes del campo de la retórica se elaboran y sistematizan a partir del siglo XII (por ejemplo, en el Quo ordine sermo fieri debeat de Guibert de Nogent (c. 1055-1124) ${ }^{6}$ ),

${ }^{1}$ A. Gallego, "Un aspecto de la transmisión del arte epistolar: el De conscribendis epistolis de Juan Lorenzo Palmireno o del Ars dictaminis a la Carta de favor", en L. González (ed.), Hommage à André Gallego: La transmission de savoirs licites ou illicites dans le monde hispanique péninsulaire (XIIe au XVIIe siècles), CNRS-Université de Toulouse-Le Mirail, Toulouse 2011, pp. 453-466.

2 A. Alberte, "Las «Artes Dictaminum», o. c., p. 253.

3 "Chapter VI. Ars praedicandi: The Art of Preaching", en Rhetoric in the Middle Ages, o. c., pp. 269-355.

4 "First Part: Artes Praedicandi", en M. G. Briscoe - B. H. Jaye, Artes Praedicandi and Artes orandi. Brepols, Turnhout 1992, pp. 11-76.

${ }^{5}$ M. G. Briscoe - B. H. Jaye, Artes Praedicandi, cit., p. 18.

${ }^{6}$ PL. 156, col. 21-32; Guibert de Nogent, Quo ordine sermo fieri debeat; De bucella iudae data et de veritate dominici corporis; De sancties et eorum pigneribus, ed. R. B. C. Huygens. (Corpus christianorum. Continuatio Mediaevalis, 127) Brepols, Turnhout 1993. Cf. J. M. Miller, “Guibert denogent's liber quo ordine sermo fieri debeat: A translation of 
cristalizando en la obra Summa de arte praedicatoria de Alano de Lille (ca. 1125-1202) ${ }^{1}$, que puede servir de criterio sobre lo que es un arte de este tipo, especialmente en esta época.

Briscoe señala algunos aspectos siguiendo a Alano de Lille, que caracterizan un ars praedicandi, que como se puede ver, en es momento de su desarrollo, no está a una gran distancia de las partes del ars dictaminis: 1) el predicador presenta un texto o cita "ab autoritate theologica"; 2) el predicador debe ganar el favor de su audiencia ("captare benevolentiam"); 3) realizado esto, el predicador expone el tema, para ello se sirve de las autoridades, también recomienda que se usen los exempla al ser estos fácilmente recordados por el auditorio ${ }^{2}$. Este esquema se profundiza con el pasar del tiempo y la introducción de los elementos aristotélicos dentro de la composición de la trama lógica y argumentativa del lenguaje y los elementos de la retórica, ganándose así en precisión expositiva, quizás perdiendo la fuerza simbólica del lenguaje que favorecía el pensamiento cristiano que había asimilado el platonismo. No obstante, la adopción de la retórica aristotélica suponía una doble perspectiva de lógica y persuasión que creo está presente en el espíritu también del predicador, pues como dice A. López, la retórica aristotélica no sigue simplemente la dialéctica, sino que se constituye como un arte que, por estar fundamentalmente enfocado al oyente, ha de adaptarse al público, al cual no puede convencerse solo por silogismos, sino que precisa ser convencido por otras estrategias persuasivas (como el carácter del orador), en consonancia con las pasiones del auditorio y que marcan el estilo del discurso ${ }^{3}$. De ahí que, quizás, vemos que la esquematización retórica va acompañada de una penetrante mirada psicológica, en el escrito de Alano, que en nuestro opúsculo no se encuentra al tener un carácter más manualístico y esquemático, y una composición en un contexto literario y de pensamiento ya posterior. No obstante, como escribe Antonio Alberte haciendo un recorrido por la retórica medieval:

"Esta obra (la de Alano de Lille) marca, pues, una notable inflexión: si por un lado todavía está vinculada a aquella tradición gregoriana, por otro, vemos cómo da paso a la modernidad. En efecto, si a la hora de señalar quién debe predicar y a quién se debe predicar, Alano está vinculado a aquella

the earliest modern speech textbook", en Today's Speech 17 (1969) 45-56.

${ }^{1}$ PL. 156, col. 109-198.

${ }^{2}$ M. G. Briscoe - B. H. Jaye, Artes Praedicandi, cit., pp. 22-23.

3 A. López, "Innovación y modernidad en la retórica aristotélica", en J. Ribeiro, A Retórica greco-latina e a sua perennidade. Actas do congreso. Instituto de Estudos Clássicos. Faculdade de Letras. Universidad de Coimbra (11 a 14 de Março de 1997), vol. 1, Fundação Eng. António de Almeida, Porto 2000, p. 117. 
tradición gregoriana, a la hora de definir la predicación y mostrarnos cómo debe ser, se revela hombre de su tiempo: para definirla utiliza los criterios dialécticos, para exponer cómo debe ser utiliza los criterios retóricos, adscribiéndole a este capítulo los géneros de discursos, las partes del mismo y la elocución"1.

Con el tiempo se mostrará una profunda caracterización de elementos retóricos e instrumentos lógicos que se harán presentes en las artes predicativas subsiguientes de una $\mathrm{u}$ otra forma. Elementos que no tienen por qué caer en contradicción y que, como señala Pedro Martín Baños, en consonancia con lo que venimos subrayando, provocan que desde el siglo XIII el ars praedicandi deba "mucho a la lógica contemporánea (y en particular al método argumentativo de la disputatio) pero que también recibe influencias innegables de la retórica ciceroniana y de las artes poetriae" 2 .

La edición de De faciebus mundi muestra la riqueza y variedad de los elementos temáticos, hasta diecinueve, entre ellos, la distinctio, la divisio, exemplificando... ${ }^{3}$ La técnica se refleja en la práctica. Estudios comparativos como los de Yuichi Akae muestran como las artes praedicandi fueron estudiadas, entendidas y utilizadas en la composición efectiva de sermones ya en el siglo XIII ${ }^{4}$.

7. El contexto de desarrollo de los tratados sobre la predicación no se circunscribe a la retórica, no tanto en el sentido de que la retórica no fuera la ciencia o disciplina en contexto de estos manuales, cuanto que su desarrollo se debe a un interés realmente pastoral: general (en el sentir de la necesidad pastoral de la Iglesia universal y local) y particular (en el sentido de que en muchas ocasiones, como la presente en el texto de Alprão, las órdenes implicadas están al servicio especial de la predicación, especialmente en el caso de la Orden de Hermanos Menores). En la actualidad ha resurgido este interés multidisciplinar (teología, predicación, catequética, literatura, cartularios...) por la riqueza que implica esta tarea pastoral que se va sistematizando y cristalizando en diversas artes como

${ }^{1}$ A. Alberte, "Retórica medieval cristiana", en Analecta malacitana electrónica 6 (2000), disponible en http://www.anmal.uma.es/anmal/numero6/Alberte.htm. Consultado el 10 de octubre de 2012.

2 P. Martín, El arte epistolar, cit., pp. 103-104.

${ }^{3}$ A. De Poorter, "Un manuel de prédication médiéval", en revue Néoscolastique de Philosophie 25 (1923) 197.

${ }^{4}$ Y. Akae, "Between artes praedicandi and Actual Sermons: Robert of Basevorn's Forma praedicandi and the Sermons of John Waldeby, OESA", en R. Andersson (ed.), Constructing the Medieval Sermon, Brepols, Turnhout 2007, pp. 9-31. 
la predicación ${ }^{1}$.

Efectivamente, la predicación es un oficio del teólogo, pero, más aún, de un teólogo franciscano. Recuerda Antonio Alberte, con razón, que la predicación medieval es una actividad teológica. Desde su conocimiento del campo de la literatura nos recuerda como en distintas obras (Verbum Abbreviatum de Pedro Cantor (†1197), Summa de arte praedicandi de Tomás de Chobham (†1327), Ad utilitatem sanctae ecclesiae catholicae de Pablo de Colonia -Kölner, Koelner (s. XIV-XV)-) la actividad está impregnada de una metodología escolástica².

Esta aportación literaria y filológica, la tematización de la predicación, no solo nace de un interés protohumanista, si bien se desarrolla en un ambiente universitario, sino que tiene presente la propia característica de la Orden de Frailes Menores desde su inicio. El menor quiere vivir en verdad y ello supone un orden de la razón y un orden en el vivir. Esto presume contar necesariamente con la razón como herramienta útil en esa investigación. Ya en vida del fundador aparece la actitud paradigmática respecto a Antonio de Lisboa/Padua (1195-1231). La búsqueda teológica se une a la predicación lo que desembocará que los franciscanos, como señala Gregorio de Nápoles, realicen sermones construidos al estilo moderno (si bien la Regla y san Francisco de Asís (1182-1226) recelaran de ellos en un inicio), llevando en sí el arte de la predicación ${ }^{3}$. El Doctor Evangélico muestra en el ejercicio de su labor predicadora el paso de universos y modelos, la combinación de un poso patrístico, un fundamento teológico de rica tradición -expresada en la predicación de la alta Edad Media- ${ }^{4}$, con nuevas formas anticipatorias de la sistematización escolástica, y, por

${ }^{1}$ R. J. Stansbury (ed.), A Companion to Pastoral Care in the Late Middle Ages (1200-1500), Brill, Leiden 2010.

2 A. Alberte, “¿Es justa la descalificación erasmiana sobre las artes predicatorias medievales?”, en Cuadernos de Filología Clásica. Estudios Latinos 15 (1998) 476.

3 Z. Zafarana, "La predicazione francescana", en Francescanesimo e vita religiosa dei laici nel'200. Atti dell'VIII Convegno della Società internazionale di Studi franciscani (Assisi, 16-18 de ottobre 1980), Università degli studi di Perugia, Assisi 1981, p. 213. Cf. Id., "Predicazione francescana ai laici", en I Frati Minori e il Terzo Ordine. Problemi e discussioni storiografiche, Atti del convegno del Centro Studi sulla spiritualità medievale, Università degli studi di Perugia, XXIII, 17-20 ottobre 1982, Accademia Tudertina, Todi 1985, pp. 171-186.

${ }^{4}$ Cf. A. Poppi, (ed.), Le fonti e la teologia dei sermoni antoniani, Atti del Congresso Internazionale sui Sermones di s. Antonio di Padova (Padova, 5-10 ottobre 1981), Ed. Messaggero, Padova 1982; R Manselli, "S. Antonio da Padova e la prima predicazione francescana”, en Il Santo 8 (1968) 2-19. 
lo tanto, de la nueva «ciencia» teológica ${ }^{1}$. La predicación franciscana se entiende dentro de la modernización del quehacer de la Orden franciscana como una nueva forma de expresión de la divisa monástica ora et labora, en la que el trabajo del conocimiento de la verdad es una devotio que terminará por convertirse en la vivencia de la misma ${ }^{2}$. En este sentido, podemos interpretar las famosas palabras de Francisco de Asís al hermano Antonio: "1. A fray Antonio, mi obispo, fray Francisco: salud. 2. Me agrada que enseñes sagrada teología a los frailes, con tal que, en su estudio, no apagues el espíritu de oración y devoción, como se contiene en la Regla"3. Efectivamente, en la Regla Bulada en su capítulo IX (De praedicatoribus), y antes de modo más extenso en el capítulo XVII de la Regla no Bulada, se establecen algunos principios sobre esta actividad que romperá las fronteras monacales, constituyendo una comunidad (fraternidad) itinerante, consagrando en la vida franciscana el estado in via propio de la antropología (y la metafísica) franciscana. Esta tarea capital en el ejercicio de la fraternidad franciscana -en consonancia con las indicaciones del canon 10 del Concilio IV de Letrán (De praedicatoribus instituendis) que realiza puntualizaciones concernientes a las nuevas Órdenes mendicantes y a los obispos y que tienen en su punto de mira las instituciones de enseñanza de la Iglesia- supone una competencia reconocida: "Y ninguno de los frailes se atreva absolutamente a predicar al pueblo, a no ser que haya sido examinado y aprobado por el ministro general de esta fraternidad, y por él le haya sido concedido el oficio de la predicación"4. La predicación pasa a ser un atributo del propio Fundador,

${ }^{1}$ Cf. C. del Zotto, "Antonio di Padova, dottore evangelico primo maestro della scuola francescana”, en Vita Minorum, 68 (1998) 252-269; A. Pompei, "The 'Sermons' of St. Anthony and Franciscan Theology”, en Greyfriars Review 9 (1995) 277-308.

${ }^{2}$ Cf., M. Lázaro "Travail intellectuel et travail physique dans la pensée franciscaine", trabajo a publicar en Mensching, G. (ed.). Col. Contradictio, Würzburg, Königshausen \& Neumann.

3 "Fratri Antonio episcopo meo frater Franciscus salutem. Placet mihi quod sacram theologiam legas fratribus, dummodo inter huius sutudium orationis et devotionis spiritum non exstinguas, sicut in regula continetur". San Francisco, Carta a san Antonio, en Los escritos de san Francisco de Asís. ed. de I. Rodríguez, A. Ortega, $2^{\mathrm{a}}$ ed. revisada por J. Ortín, Murcia, Publicaciones del Instituto Teológico Franciscano-Ed. Espigas, 2003, p. 351; A. Rigon, "S. Antonio e la cultura universitaria nell'ordine francescano delle origini", en Francescanesimo e cultura universitaria. Atti del XVI Convegno internazionale. Assisi, 13-14-15 ottobre 1988, Università degli studi di Perugia-Centro di studi franciscani, Assisi 1990, pp. 69-92.

4 "Et nullus fratrum populo penitus audeat praedicare, nisi a ministro generali huius fraternitatis fuerit examinatus et approbatus, et ab eo officium sibi praedicationis concessum". Regla Bulada, IX, 2, en Los escritos de san Francisco, cit., p. 590. Cf. F. Accrocca, 
reconocido como una de las características de su misma santidad ${ }^{1}$.

Sin duda alguna, este paso fue fundamental en la apertura de la Escuela franciscana hacia la búsqueda de la verdad y ello de una forma filosófico-teológica, explicando la relación profunda del arte de predicación a la forma mental franciscana (pastoral y especulativa). La trascendencia en este momento del recurso del sermón y la predicación como correa de transmisión del pensamiento y método de penetración especulativa se traslada al mismo quehacer universitario. Si reparamos en las nuevas universidades, de forma especial en la de París, podemos constatar que el estudio de la teología se desarrolla junto al de la predicación ${ }^{2}$, así podemos ver a principios del siglo XIV (sermones magistrales en los estatutos de París o en Oxford el sermo publicus o sermo generalis ${ }^{3}$ ), como una práctica consagrada en la norma estatutaria, la inclusión del deber de predicar sermones en las iglesias por parte de los miembros docentes y estudiantes- de la Facultad de Teología, de modo especial en las fiestas litúrgicas ${ }^{4}$. De este modo, los primeros teólogos franciscanos,

"La predicazione francescano intorno a Reg. Bull. IX", en P. Maranesi (ed.), Negotium Fidei. Miscellanea di studi offerti a Mariano D'Alatri in occasione del suo $80^{\circ}$ compleanno, Istituto Stórico dei Fratri Cappuccini, Rome (Bravetta), 2002, pp. 107-125.

1 "Più tardi, nella bolla di canonizzazione di Francesco, la Mira circa nos, Gregorio IX offrì una rilettura globale dell'esperienza cristiana del Santo di Assisi, fornendo in tal modo ai Frati Minori - ed era proprio questo il suo obiettivo principale - un chiaro e autorevole indirizzo circa la loro missione ecclesiale: non era la vita evangelii, la testimonianza silenziosa e priva di tutto, espropriata di ogni attesa nei riguardi degli altri, a costituire l'elemento qualificante della scelta di Francesco, ma la sua predicazione che, per quanto semplice, aveva il potere di risanare e fecondare. Sull'incontro con i poveri e i lebbrosi, che Francesco aveva individuato come il momento cruciale del suo processo di conversione, neppure una parola". F. Accrocca, "Dall'alternanza all'alternativa Eremo e città nel primo secolo dell'Ordine francescano: una rivisitazione attraverso gli scritti di Francesco e le fonti agiografiche", en Via spiritus 9 (2002) 17.

2 Cf. J. Hamesse, "La prédication universitaire", en La predicazione dei fratri dalla metà del '200 alla fine del '300. Atti del XXI Convegno internazionale, Assisi 13-15 ottobre 1994, C.I.S.A.M., Spoleto 1995, pp. 49-79. Cf. M. D’Alatri, "La predicazione francescana nel due e trecento", en Picenum seraphicum. Rivista di studi storici locali a cura dei frati minore delle marche 10 (1973) 7-2

${ }^{3}$ Cf. O. Weijers, Terminologie des universités au XIII siècle, Edizioni dell' Ateneo, Roma 1987, pp. 378-381.

4 "Statuta universitatis parisiensis de ordine legend. Regule speciales pro qualibet facúltate. Et primo pro theologis (a): ...(4) Item, nota, quod quando theologi habent aliquod festum, quo ipsi non legunt, licet in illo festo legatur in aliis facultatibus, nichilominus in ilia die fit sermo de mane, et collatio in vesperis in Cordigeris, vel in Jacobitis. (5) Item, nota, quod quando magistri in theologia legunt in primis, tunc bachalarii legentes Sententias illis diebus legunt in tertiis; alias semper legunt Sententias in primis Sancti 
en la fase embrionaria, es decir, entendamos la época que gira alrededor del magisterio de Alejandro de Hales (ca. 1183-1245), desarrollan la especulación teológica en torno a la mejora sistemática de la técnica de los sermones. Así, en una transición que se va realizando en sintonía y de forma retroalimentada ${ }^{1}, \operatorname{los}$ franciscanos introducen en su metodología docente la lectura de las Sentencias y de esta forma la vida en la Verdad y su correcta predicación va a ser alimentada en una búsqueda "teológica", toda vez que el comentario a la obra de Pedro Lombardo (ca. 1100-1160) constituye, como sabemos, el elemento fundamental del currículo de la Facultad de Teología. La teología y la escolástica están al servicio de una predicación más apegada a la transición de un contenido, digamos dirigida al pueblo, a diferencia del objetivo eclesial-pastoral de los dominicos y eso se deja notar en las propias artes praedicandi: "Umbero de Romans - escribe Carlo Delcorno- en la más antigua ars praedicandi dominicana, define su papel de Predicador con metáforas ligadas al campo semántico de la diplomacia"2. A pesar de que, como ya señalamos, posiblemente en esta literatura esté presente el tono diplomático traído también de las artes dictaminis que influyen en estos manuales, sin embargo, parece significativo que el propio carisma de la Orden franciscana, diferente del dominicano, influye, sin duda, en la estructuración material y formal del sermón y de la predicación.

8. La idiosincrasia de la predicación popular franciscana, aún desde su asentada tradición escolástica, creo que ayuda a comprender mejor (no únicamente) la obra de Alprão. La señalada formalidad del opúsculo, la

Jacobi predicti bachalarii. [Au Cordelières (Cordigeris) pour les Mineurs; au St. Jacques (Jacobitis) pour les Dominicains]". Chartulatium universitatis Parisiensis, vol. II, ed. H. Denifle, E. Chatelain, Paris 1889-1897, n. 1188, p. 692. Cf. P. B. Roberts, "Medieval University Preaching: The Evidence in the Statutes", en J. Hamesse - B. M. Kienzle - D. L. Stoudt - A. T. Thayer, Medieval sermons and society: cloister, city, university, FIDEM, Louvain-la-Neuve 1998, pp. 317-328; J. Hamesse, "La prédication universitaire: éloquence sacrée, éloquence profane?", en Ephemerides Liturgicae 105 (1991) 283-300.

${ }^{1}$ Alexander of Hales, Quaestio de officio praedicationis, en Magistri Alexandri de Hales, Questiones disputatae 'Antequam esset frater', I, q. xxix, Quaracchi, Florentiae 1960, pp. 516-527. Cf. J. B. Schneyer, "Eine Sermonesreihe des Magister Alexander von Hales in der Hs. Pavias, Univ Aldini 479", en Archivum Franciscanum Historicum, 58 (1965) 537-551; L. -J. Bataillon, "Sermoni e orazioni d'ambienti universitario parigino nel sec. XIII”, en Documenti e studi sulla tradizione filosofica medievale, 5 (1994) 297-329.

2 "Umberto di Romans nella più antica ars praedicandi domenicana defini sceil ruolo dei Predicatori con metafore attinte al campo semantico della diplomazia". C. Delcorno, "Predicazione volgare e volgarizzamenti", en Mélanges de l'École française de Rome. Moyen-Age, Temps modernes 89 (1977) 680. 
utilización paradigmática de los ejemplos (exempla) no se debe exclusivamente a razones literarias, sino a la elección de técnicas acordes con la intención de la predicación que se insertan en el manual. La afirmación de Carlo Delcorno de que: "Francisco de Asís privilegia los temas políticos, y en primer lugar el de la paz, y lo presenta con inmediatez juglaresca, relegando las rationes, a favor de los exempla, evitando la exégesis para insistir sobre la letra de la Escritura"3, cobra sentido práctico - más allá de otras consideraciones- en el ars praedicandi de Alfonso de Alprão, obra en la que se confirma lo que el mismo autor recuerda en otros escritos cuando afirma que: "En general las «pruebas y verdades» parecen más importantes en los Dominicos, mientras que en los Franciscanos, se da más espacio a los Exemplum, que con frecuencia son transformados en una imitación verdadera desde una historia"4 .

Fondo franciscano, y formación escolástico-retórica se unen. Especialmente en los cortos manuales de finales del s. XIV y el s. XV -posiblemente, como es nuestro caso, ajenos a la influencia directa de las universidades inglesas y franceses- como los peninsulares del agustino Martín de Córdoba y el también franciscano Francesc Eixemenes, en los que se privilegian los aspectos esenciales de la producción de las predicaciones sobre la exposición y compilación, en este sentido esquematizando el desarrollo temático de los manuales del siglo XIII de Juan de la Rochelle $(\dagger 1245)$, Juan de Gales $(\dagger 1285)$ y el Pseudo-Buenaventura que como se ha afirmado "fijan su atención exclusivamente en el desarrollo del tema, esto es, en la exposición de las partes del sermón: la atención a aquellos otros aspectos relativos a la formación del predicador, a la

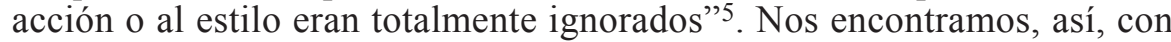
artes predicatorias apegadas a formas nacientes del método escolástico. La separación en tres partes teóricamente principales del ars praedicandi de Alprão en introducción, división y distinción (si bien casi toda la obra se centra en la primera), así como el recurso a la estructura argumentativa, es reflejo de esta evolución escolástica (por otra parte, la argumentación de corte dialéctico y la influencia filosófica tendrá una notable influencia en ciertos juristas, especialmente en los doctores moderni ${ }^{6}$, circunstancia

3 "Francesco d'Assisi privilegia i temi politici, e in primo luogo quello della pace, e li esprime con immediatezza giullaresca, tralasciando le rationes a vantaggio degli exempla, evitando l'esegesi per insistere sulla lettera della Scrittura". Ibid., 681.

4 "In general «proofs and truths» seemed most important to the Dominicans, while is often transformed from a story in a true mime". C. Delcorno, "Medieval Preaching in Italy (1200-1500)", en B. M. Kienzle, The Sermon, cit., p. 474.

5 A. Alberte, "Retórica medieval", cit.

${ }^{6}$ O. Weijers, Queritur utrum. Recherches sur la 'disputatio' dans les universités médiévales, Brepols, Turnhout 2009, p. 168. 
que no puede ser obviada por el predicador). A su vez, la influencia en la temática desarrollada en el capítulo sobre la introducción al sermón de las artes dictaminis y los recursos relativos a las condiciones del tema y su desarrollo rimado, la utilización de las concordancias..., así como las técnicas de desarrollo del sermón que despliega este opúsculo nos muestran, en sintonía con lo que acaece en otros artes predicatorias del s. XIV, el recurso a medios más propios de la retórica clásica.

En este sentido, destaca como hemos señalado, especialmente en el arte predicatoria de Alfonso de Alprão, la utilización de los exempla, pero en el contexto de la auctoritas, es decir de la citación bíblica del tema, pues la introducción del mismo es vital en este arte de predicación. La utilización de los ejemplos se inserta de forma que lo que se hace es intentar dar viveza retórica, apostando por el desarrollo de un esquema de la retórica aristotélica que, siguiendo a Jacobo de Vitry (c. 1160/70-1240), Bremond, Le Goff y Schmitt han reducido a tres categorías, que si bien no se siguen al pie de la letra ayudan a leer mejor el Ars praedicandi de Alfonso de Alprão:

"consideraremos sucesivamente las tres categorías mayores de la retórica aristotélica: su eje paradigmático, o inventio, es decir la reunión de los instrumentos retóricos que serán utilizados; el eje sintagmático, o dispositio, es decir la combinación ordenada de los instrumentos; la realización práctica del conjunto, o elocutio, que plantea el problema de la relación entre el predicador y su público"1.

De esta forma, el ejemplo desarrolla la autoridad temática, normalmente una autoridad bíblica. Recordemos que el significado del término exempla es amplio; en este sentido, entendamos los "ejemplos" o el "ejemplo" (exemplum) como lo delimita Claude Bremon, Jacques Le Goff y Jean-Claude Schimitt en la acepción de "argumento narrativo que viene de la gramática y de la retórica, pero que en la escolástica de los siglos XII-XIV tienden a confundirse con el exemplum lógico y filosófico que, frecuentemente en la tradición neoplatónica, tiene el sentido de arquetipo y

1 "On conduira l'analyse en considérant successivement les trois catégories majeures de la rhétorique aristotélicienne: son axe paradigmatique, ou inventio, c'est la réunion des instruments rhétoriques qui seront mis en œuvre; l'axe syntegmatique, ou dispositio, c'est-à-dire la combinaison ordonnée de ces instruments; la mise en œuvre pratique de l'ensamble, ou elocutio, que pose le problème du rapport entre le prédicateur et son public". C. Bremon - J. Le Goff - J.-C. Schimitt, L' "exemplum”, Brepols, Turnhout 1982, p. 154. Cr. C. Delcorno, Exemplum e letterature tra Medievo e Rinascimento, Il Moulino, Bologna 1989. 
modelo"1. Estos ejemplos son de una gran difusión y utilización a lo largo de la historia de la retórica y en la Edad Media, especialmente, pero no solo, en funciones pastorales. Desde el siglo XIII, y como estamos viendo, se insertarán en el sermón medieval adquiriendo nuevas características. El ejemplo medieval inserto en el sermón se puede definir como "un relato breve tenido como verídico y destinado a insertarse en un discurso (en general o sermón) para convencer un auditorio para realizar una lección salvífica"2. Tomás Waleys (s. XIV) distingue tres tipos de argumentos en la predicación (en las Artes praedicandi): las autoridades (auctoritates), las razones (rationes) y los ejemplos (exempla). Los ejemplos cristianos son una adaptación de los latinos, y se vinculan con la temática bíblica, especialmente a partir de la acomodación de Tertuliano, utilización recomendada por san Agustín ${ }^{3}$. Si es cierto que los medios monásticos, urbanos y universitarios son entornos culturales que influyen en la realización específica de los mismos, no es menos cierto que el contexto pastoral y predicativo (o sermocinal) ligado a la temática cristiana permanece: por una parte la temática nacida de la autoridad bíblica, principalmente; por otra parte el modelo: por excelencia la Virgen María, fuente de exempla vivendi -como expresa san Anselmo (1033-1109)-, le siguen los mártires y los santos.

Especialmente reseñable resulta la elección de la auctoritas y del modelo, que se centra en un tema mariano, lo que está en consonancia con lo que acabamos de exponer, pero, también, se contextualiza en el pensamiento de la Orden. En esta introducción no podemos abordar el tema de la mariología franciscana, de gran importancia ya en el pensamiento de san Francisco de Asís y recurrente en los tempranos escritos de san

1 'L'exemplum dont nous parlons ici, c'est donc l'exemplum comme argument narratif et il relève de la grammaire et de la rhétorique. Mais la scolastique des XII - XIVe siècles a tendance à le confondre avec l'exemplum logique et philosophique qui, le plus souvent dans la tradition néo-platonicienne, a le sens d'archétype et de modèle”. Ibid., p. 28.

2 Ibid., 38. Cf.

3 "Los escritores de la patrística mediante formas narrativas analógicas breves -entre ellas el exemplum y la similitudo- intentan un hacer exegético de los preceptos cristianos y dogmáticos destinado a un colectivo inmenso en creencias atávicas que necesitaba ser adoctrinado con referencias continuas a las escrituras bíblicas, milagros de Santos, a fenómenos de historia natural $\mathrm{y}$, en menos medida, a relatos profanos. Sus homilías no se vertebran y organizan mediante estrategia retórica alguna. El ejemplo va surgiendo como prueba o ilustración del desarrollo moral o doctrinal que se expone". J. Lozano, "Introducción", en Gesta Romanorum, intr. y not. J. Lozano, trad. V. de la Torre, Akal, Madrid 2004, p. 26. Sobre la utilización de la retórica por parte de los Padres en la homilética, cf. P. Barata, "A retórica clássica e a homilética cristã”. en J. Ribeiro (ed.), A Retórica greco-latina, vol. 2, cit., pp. 613-629. 
Antonio de Lisboa/Padua ${ }^{1}$ ), pero sí que podemos recordar que el siglo XIV vive la controversia mariológica de la Inmaculada concepción de una forma tan viva que sale de los claustros universitarios y las discusiones escolásticas -desde la defensa escotista del dogma y al que se suman figuras franciscanas como Pedro Aureolo (ca. 1280-1322), Francisco Mairón $(\dagger 1328)$ y Pedro Tomás (1280-1340), como otros de otras órdenes, es el caso del carmelita san Pedro Tomás (1305-1366) e incluso algunos dominicos como Juan Taulero (ca. 1300-1361) o el español Vicente Ferrer (1350-1419)2 -, para convertirse en el "sujeto de la predicación no solo ad clerum sino también ad populum"3, una divulgación en la que destacará la predicación de Bernardino de Siena ${ }^{4}$. Efectivamente, el tema propuesto como modelo se refiere a una autoridad, tomada de una cita bíblica del Apocalipsis (Ap. 12, 1) en honor a la Virgen María en la festividad de la Asunción, que ya en Antonio de Lisboa/Padua aparece ligado a la liberación del pecado ${ }^{5}$, de modo que junto a la figura de la santificación inmaculada de la Virgen María se señala la función redentora de la Madre de Dios ${ }^{6}$, algo que será repetido por los maestros franciscanos ${ }^{7}$, por lo

${ }^{1}$ Cf. M. Steiner, "San Francisco y la Virgen María”, en Selecciones de Franciscanismo 10 (1981) 53-65 P. de Anasagsti, "Principios teológicos de la piedad mariana de San Francisco de Asís", en Estudios Marianos 48 (1984) 389-417; B. Costa, La mariología di S. Antonio di Padova, Il Messaggero di S. Antonio, Padua 1950; G. Calvo, "Santa María, Madre de Dios, en los sermones de S. Antonio de Padua", en Verdad y vida 13 (1955) 331-348.

${ }^{2}$ Cf. I. Brady, "The Development of the Doctrine on the Immacultae Conception in the Foruteenth Century after Aureoli”, en Franciscan Studies 15 (1955) 175-202.

3 "Le XIVe siècle vit la controverse autour de la conception de Marie sortir du cadre des débats scolastiques pour devenir un sujet de prédication non seulement ad clerum mais également ad pupulum". R. Gay-Canton, Entre dévotion et théologie scolastique. Réceptions de la controverse médiévale autour de l'Immaculée Conception en pays germaniques, Brepols, Turnhout 2011, p. 315.

${ }^{4}$ Cf. A. Pompei, "L'Immacolata Concezione e i teologi francescani del secolo XIV", en Virgo Inmmaculata 7 (1957) 241-271.

${ }^{5}$ El tema del pecado original es, de por sí, un recurso utilizado en el contexto temporal de Alfonsdo de Alprão. Adeline Rucquoi señala desde le punto de vista literario, pero quizás olvidando la reflexión filosófica y teológica esta impotante reflexión en la configuración de la Corona de Castilla y la renovación teológica. Cf. "Mancilla y limpieza. La obsesión por el pecado en Castilla a fines del siglo XV", en Revista da Faculdade de Letras - Linguas e Literaturas Anexo VIII - Os "últimos fins" na cultura ibérica (XV-XVIII) - (1997) 123.

${ }^{6}$ Cf. B. Aperribay, "La Asunción de la Virgen según san Antonio de Padua", en Verdad y vida 4 (1946) 697-710.

7 Cf. F. J. Mac Mahon, "La muerte y la Asunción de María según los teólogos franciscanos", en Itinerario 6 (1949) 267-293. 
que no extraña el recurso a un lugar recurrente para indicar la Corona (de la Asunción) en honor a su Inmaculada concepción: "En su cabeza la corona" (In capite eius corona).

En fin, el profesor João Francisco Marques señala cómo los objetivos de estos exempla en los sermones, especialmente de los mendicantes "expraiam-se pelo doutrinário teológico e ético-normativo, cristológico e mariano, panegírico, exegético-alegórico, ascético-místico e pastoral" 1 .

9. Efectivamente, en la Península Ibérica, en consonancia con las indicaciones del IV Concilio Lateranense (1215), no faltan las exhortaciones específicas al clero y a los religiosos de una especial cura de almas, ante cierta negligencia del clero ${ }^{2}$, que tenga en cuenta la predicación. Se pueden observar en concilios particulares (sínodos diocesanos y concilios provinciales y en recomendaciones más generales como pueden ser los concilios de Valladolid $(1228,1232)$ y Lérida (1229) en el siglo XIII, o el de León (1303) o Salamanca (1396) en el siglo XIV). El profesor João Francisco Marques inserta nuestro opúsculo dentro de los textos parenéticos o de predicación que tienen en san Antonio de Lisboa/Padua y Fray Paio de Coimbra ( $\uparrow$ ca. 1250) unos inicios que en no pocas ocasiones constituyeron las fuentes principales de legitimación del poder político y establecimiento social ${ }^{3}$ y que va evolucionando, sin olvidar estas funciones; pero imbuyéndose, como en el resto de los territorios cristianos, del espíritu escolástico y humanista. La época de Alfonso de Alprão, conoce una serie de autores religiosos que ya tienen asumido una tradición, aunque se plantean problemas respecto al modelo que se siguen en los sermones peninsulares del siglo $\mathrm{XIV}^{4}$.

"No século XIV -escribe el professor portugués-, conhecem-se: o carmelita Alfonso Abelho que pregou na Sé de Evora, por ocasião de uma inundação, com muito fruto nos ouvintes; os dominicanos Fr. Rodrigo do Porto, doutor com pregação referente a 1381 e 1391; Fr. Pedro Correia que estudou

1 J. F. Marques, “A pregação medieval portuguesa”, en L. A. Da Fonseca - L. C. Amaral - Ma F. F. Santos, Os reinos ibéricos na Idade Média. Livro de Homenagem ao Professor Doutor Humberto Carlos Baquero Moreno, vol. II, Livraria Civilização Editora, Porto 2003, p. 605.

${ }^{2}$ Cf. V. Beltrán de Heredia, "La formación del clero en España durante los siglos XII-XIV”, en revista Española de Teología 6 (1946) 301-357.

${ }^{3} \mathrm{Al}$ respecto cf. la tesis doctoral en Letras (História da Idade Média) de José Antunes: A cultura erudita portuguesa nos séculos XIII e XIV: juristas e teólogos presentada en la Facultad de Letras de Coimbra el 12 de febrero de 1996. Texto policopiado. Coimbra 1995.

4 "What happens, then, during the thirteenth century and most of the fourteenth century?". M. A. Sánchez, "Vernacular preaching in Spanish, Portuguese and Catalan", en B. M. Kienzle, The Sermon, Brepols, Turnhout 2000, p. 784. 
em Oxford (1394); Fr. Vicente de Lisboa (m. cerca de 1408), estudante em Oxford, confessor de D. João I e fundador do convento de Benfica; os franciscanos Fr. Alfonso de Alprão, estudante em Bolonha, teólogo, confessor régio, autor de uma «Ars praedicandi»; Fr. João de Xira, natural do Porto, confessor de D. João I, com presença no Concílio de Pisa e pregador em Lagos da Bula da Cruzada, aquando da expedição a Ceuta, e na purificação da mesquita, sagrada templo católico; Fr. Pedro, teólogo e pregador na vitória de Aljubarrota; Fr. Rodrigo de Sintra, teólogo e orador no levantamento do cerco de Lisboa (1384) durante a crise dinástica; Fr. Salvado Martins, confessor da Rainha Santa Isabel e bispo de Lamego, falecido em 1349; Fr. Tomás ou Tomé de Portugal, docente nas Universidades de Inglaterra, Espanha e Paris"1.

Se trata de una lista que se multiplica significativamente en los dos siglos que le siguen y que João Francisco Marques ha publicado ofreciendo un catalogo amplio. Un impulso que se reflejará en la Orden franciscana con el paso del tiempo y que ayuda a entender otras tradiciones espirituales y teológicas dentro de la Orden que concretan su espíritu. La retórica seguirá siendo, ya desde las profundidades intimistas de la espiritualidad, lugar de solaz ante la turbación intelectual de la mentalidad ilustrada ${ }^{2}$. Una amplia lista que supone una extensión, cada vez más frecuente, de la doctrina al pueblo. El hecho de la existencia del latín en los sermones y en los tratados no es significativo. Por una parte, en los tratados y manuales el uso del latín es lógico en la metodología universitaria, pero, además, no se puede afirmar de una forma tajante y descontextualizada que el sermón o la predicación en latín o en lengua vernácula sea el criterio de demarcación tanto del sermón como del público al que está destinado. Como con acierto señala Réjane Gay-Canton, a lo sumo podemos hablar de tendencias en el auditorio, los litterati, que serían en su mayor parte el clero regular y secular, y los illitterati, formados tanto por religiosos como por laicos; de modo que "comprender la literatura latina como una literatura destinada a los litterati y la literatura vernácula como destinada a los ilitterati aparece como insuficiente"3.

Al contexto cercano e ibérico se le suma el contexto de Bolonia (lugar

${ }^{1}$ J. F. Marques, “A pregação medieval”, cit., pp. 614-615.

2 El Plan de Estudios franciscanos ideado por el P. Martín en 1786 invita a que los estudiantes de filosofía lean en periodo estival (pues no existían vacaciones) la retórica del P. Granada. M. R. Pazos, Los estudios en la Provincia Franciscana de Santiago (Tratado histórico), Madrid 1967, p. 39. Estudios que se realizaban, por otra parte en todas las disciplinas, especialmente en los Colegios de Moral, siguiendo ya manuales más elaborados como los del P. Digo de Estella (pp. 65, 68).

3 “...comprendre la littérature latine comme une littérature destinée aux litterati et la littérature vernaculaire comme destinée aux ilitterati s'avère insuffisant”. R. Gay-Canton, Entre dévotion et théologie scolastique, cit., p. 20. 
en que Alfonso de Alprão compuso su Ars praedicandi). La Universidad italiana se constituyó en una institución esencial en la formación teológica y canónica, no sólo en la formación de las órdenes religiosas, sino también y, especialmente, de los canónigos y el clero secular. Muestra de ello es la institución, por parte del cardenal Albornoz, en 1371, del Colegio Español de Bolonia (Colegio Mayor de San Clemente de los Españoles ${ }^{1}$ ) en el que se encontraban una buena cantidad de bachilleres venidos de cabildos catedralicios ${ }^{2}$. La Universidad de Bolonia como las diferentes universidades, tal como hemos señalado, incluía en sus estatutos la realización del ejercicio de la predicación. La inclusión de esta actividad en los estatutos se realiza desde el inicio de la actividad de la Facultad de Teología mediante el privilegio concedido por el papa Inocencio VI, enfatizándose los estudios en cánones (la Universidad de Bolonia es la que tuvo la primera Facultad de Derecho en Europa desde que Honorio III atribuye al Archidiácono de Bolonia la facultad de conceder la licencia docendi y que beneficia el estudio del Derecho canónico en Bolonia y Teología en París en la bula Super speculam ${ }^{3}$ ). En 1364 los estatutos de la Universidad (que se redactan desde 1317 hasta 1432, en parte a partir de los estatutos de $1252^{4}$ ) aseguran la preparación del trabajo de predicador y confesor. La iniciativa boloñesa se transmite a otras instituciones italianas como Padua, Perugia, Florencia o Parma, pues se constituyó en modelo para muchas instituciones. El sermón no solo afecta a los estudios teológicos y jurídicos, sino que se introducen en los estatutos de la Facultad de Medicina, donde el doctor más antiguo tiene la obligación de realizar un sermo universitatis o generalis. Efectivamente, en Bolonia, los docto-

${ }^{1}$ Cf. B. M. Marti, The Spanish College at Bologna in the Fourteenth Century, University of Carolina Press, Philadelphia, 1966. Este Colegio tuvo una significativa importancia en siglos posteriores, Cf. D. de Lario, "La Universidad de Bolonia y el Colegio de España en el tránsito de los siglos XVI al XVIII”, Estudis 8 (1980) 7-23.

2 J. M. Nieto - I. Sanz, La época Medieval: Iglesia y Cultura, Akal, Madrid 2002, p. 171.

${ }^{3}$ J. García, "El «modelo boloñés» de Universidad. Imagen jurídica e historiográfica", en L. E. Rodríguez-San Pedro y J. L. Polo, Universidades clásicas de la Europa mediterránea: Bolonia, Coimbra y Alcalá, Ediciones Universidad de Salamanca, Salamanca 2006, p. 27.

${ }^{4}$ Cf. C. Malagola, Statuti delle Università e dei Collegi dello Studio Bolognese, Nicola Zanichelli, Bologna 1888 (reimpr. anast. Bottega d'Erasmo, Torino 1966); C. Piana O.F.M., Nuove ricerche su le università di Bologna e di Parma, Quaracchi, Firenze 1966. Los estatutos de la Facultad de Teología se conceden en 1360, pero no se inauguraría la Facultad hasta cuatro años más tarde. Cf. H. Rashdall, The Universities of Europe in the Middle Ages. Vol. 1 (Salerno, Bologna, Paris), ed. F. M. Powicke - A. B. Emden, Oxford University Press, Oxford, 1895 (reimpr. Sandpiper Bokks, 1997), pp. 250-252. 
res han de realizar ejercicios de oralidad pública cuando se les confiere el grado en los llamados exámenes publica o conventus ${ }^{1}$. Este ambiente no puede olvidarse. Así, la Universidad de Bolonia contaba con una gran tradición y predicamento dentro de los estudios especialmente jurídicos, una tradición que influye tanto en otras universidades italianas como en las de la Península Ibérica y las del Mediodía francés ${ }^{2}$. Pero al tiempo que Bolonia servía de modelo, recibía sus influjos también de aquellas con las que mantenía una correspondencia académica; en este sentido de las escuelas de Orleans y Tours, Bolonia irá recibiendo el influjo de las artes retóricas que hemos mencionado: ars poetriae, ars dictaminis, ars arengandi y con el tiempo el ars memorativa, ya a partir del s. $\mathrm{XV}^{3}$. De hecho, durante los siglos XIV y XV en Bolonia - y las universidades de su influjo- se mantienen y cuidan las artes dictaminis y las artes pradicandi, manteniéndose e introduciéndose más incisivamente los contenidos retóricos ciceronianos en los que las artes arengandi se desarrollan a la par y muestran una evolución humanista, simbiosis temática que se muestra en la obra de Alfonso de Alprão: "Incipit Ars Praedicandi, conferendi, collationandi, arengandi, secundum multiplecem modum, etcétera".

La unión humanista de los estilos refleja una asimilación de los esquemas presentes en las artes que le son cercanas, asimilando la estructura y el estilo del sermón italiano caracterizado por la elección de un verso bíblico como tema. Como señala Michel Zink, el tema elegido, su extensión, la forma en que se comenta es esencial al sermón, y las Artes praedicandi lo confirman en la importancia que confieren a la introducción y división del tema ${ }^{4}$. Este tema se desarrolla en Alfonso de Alprão insistiendo en la "introducción del tema" en el que se esclarece el propósito general del sermón que ha de ser predicado, una introducción de una importancia tal que parece que ejerza las funciones de un protema. Este es el punto distintivo del opúsculo, las otras dos partes división y distinción sigue el desarrollo del sermón que verá su ejemplo y paradigma posterior en Bernardino de Siena ${ }^{5}$, retomadas desde la tradición; pero en las que se

${ }^{1}$ P. B. Roberts, "Medieval University Preaching", cit., pp. 69-70.

2 A. García y García, "La enseñanza del derecho en la universidad medieval", en J. Hamesse (ed.), Manuels, programmes de cours et techniques d'enseignement dans les universités médiévales. Actes du Colloque international de Louvain-la-Neuve (9-11 septembre 1993), Publications de l'Institut d'Études Médiévales, Louvain-la-Neuve 1994, p. 202.

${ }^{3}$ P. Martín, El arte epistolar, cit., p. 103.

${ }^{4}$ M. Zink, La prédication en langue romane avant 1300, Éditions Champion, Paris 1982, p. 221.

5 Cf. C. Delcorno, "L'ars praedicandi di Bernardino da Siena", en D. Maffei - P. Nardi, Atti del Simposio Internazionale cateriniano-bernardiniano. Siena, 17-20 April 1980, Accademia senese degli Intronati, Siena 1982, p. 422. 
conceden una división exterior al tema, circunstancia al gusto de este arte más desarrollado. Algo similar se puede observar en las rimas y etimologías presentes de forma recurrente en el opúsculo, técnicas que vienen de la tradición del sermón y al que se le suma, en nuestro Ars praedicandi, el gusto por la recuperación de una retórica al uso de la época. Se trata de "dos características estilísticas propias de los sermones romanos" ${ }^{1}$ y que tratadas en la predicación toman un sentido particular. Los juegos de palabras y los fragmentos rimados están en el origen del sermón tardomedieval en los que se encuentran con gran frecuencia y extensión ${ }^{2}$ y se recupera en esta época en la tipicidad humanista, mostrando el género sermocinal y predicativo la línea de continuidad en el ritmo que se va desarrollando de Cicerón a el Brocense, como mostrara el profesor E. Sánchez Salor ${ }^{3}$. Quizás pueda constituir este opúsculo una piedra en el camino de construcción que se hace en tierras portuguesas con la llegada del franciscano, el camino de enriquecimiento marcado por André Resende en la Oratio pro rostris (1534) y que Anibal Pinto de Castro señalara sobre la continuidad de la tradición retórica en Portugal, en su estudio "Entre Cícero e Aristóteles. A retórica em Portugal, do Renascimento ao Barroco"4. En la descripción de este contexto se puede vislumbrar el porqué de las partes del Arte de la predicación de Alfonso de Alprão: introducción del tema, división y distinción. Estructura que puede hacer comprender y divulgar la estructura y el estilo de los sermones y los artes de predicación en la Península Ibérica.

\section{Algunas notas filológicas a la traducción del Ars praedicandi de Alfonso de Alprão}

Sin duda alguna, este tipo de traducción que hemos abordado supone un reto muy importante. El Medieval es un latín que, siguiendo leyes de universalidad lingüística, es el resultado de un proceso de transformación a partir de sus modelos. Ello no quiere decir que se haya empobrecido sino que, simplemente, no es el mismo latín que el de los autores clásicos. Esta transformación viene marcada por el sincretismo de casos, declinaciones...; por el paso de un sistema más sintético a un sistema más analítico; por la introducción de neologismos... Además, los distintos autores, a pesar

${ }^{1}$ M. Zink, La prédication, cit., p. 271

2 Ibid.

3 E. Sánchez, "El ritmo en prosa. De Cicerón a el Brocense", en J. Ribeiro (ed.), A Retórica greco-latina, vol. 2, cit., 569-592.

${ }^{4}$ En J. Ribeiro (ed.), A Retórica greco-latina, vol. 2, cit., 895-210. 
de que cuentan con una excelente formación en lengua latina, apuntalada sobre el contexto de la época, deslizan involuntariamente rasgos propios de sus lenguas maternas en los diferentes textos, lo cual obliga a tener en cuenta alguna de sus construcciones más recurrentes. Sin embargo dos cosas son ciertas: que al igual que todos los de su época, tenía un dominio del Latín cercano a la maestría y que, aun así, pueden rastrearse en la obra construcciones propias de la lengua portuguesa que han sido directamente trasladadas al Latín.

Después de estas breves reflexiones sobre la situación del Latín Medieval, procederemos a analizar más concretamente con qué problemas de traducción nos hemos encontrado en el Ars praedicandi de Alfonso de Alprão:

Variantes reales ${ }^{1}$. Esta dificultad supone la existencia de realidades en la lengua de origen que no se dan en la cosmovisión de la lengua de destino. Esta supone sin duda una de las mayores frustraciones para un traductor ya que le obliga a "rendirse" en su tarea de trasladar un texto de una lengua a otra. Ha de optar entonces con tomar la palabra y, sin traducirla, insertarla como una cuña, con la ayuda del aceite de una nota del traductor. Es lo que sucede, por ejemplo, en el Ars praedicandi con la palabra dictator. En el ámbito de la formación para la predicación y la homilética, tal como se ha señalado en líneas anteriores: "La actividad de dictar (dictare) era realizada por el dictator, el maestro de este arte de dictar, quien se encargaba de forma oficial de escribir y componer (puesto que el dictare era tomado en el sentido de componer) las cartas (dictatos). Y precisamente para poder realizar de forma más fácil esta tarea se redactaron las Artes dictaminis o Artes dictandi" 2 . A la hora de trasladar esta palabra y su contexto a la lengua de destino, no encontramos ningún significante que reproduzca los significados (y mucho menos los sentidos) presentes en el término latino. La situación podría quedar hipotéticamente resuelta si optamos por la evolución fonética y utilizamos el término dictador en cuanto a persona que dicta algo a alguien que escribe. Sin embargo, en este caso nos encontramos con un agravante cual es el de las connotaciones negativas que adquiere la palabra dictador en nuestro idioma. Por ello hemos optado por mantener, cuando la situación lo requiera y en aras a la precisión, los términos en latín.

${ }^{1}$ M. Casas, "Realidad, cultura y variación: las variantes reales", en M. Casado - R. González - Ma V. Romero (eds.), Análisis del discurso: lengua, cultura, valores. Actas del I Congreso Internacional (Universidad de Navarra, Pamplona, noviembre de 2002), vol. I, Arco/Libros, Madrid 2006, pp. 289-298.

2 Cf. M. Camargo, Ars Dictaminis, o. c., p. 17 
Términos especificos. El texto de Alprão se inserta dentro de una tradición didáctica en torno a cómo elaborar homilías. Como hemos visto en el apartado anterior, se trata de un campo de conocimiento muy específico que cuenta con una terminología propia, es decir, vocablos que poseen un contenido muy restringido y claro con respecto al universo conceptual que virtualmente pueden representar. Sucede por ejemplo con términos como originalis. Así, por ejemplo, el adjetivo latino originalis, en este contexto tan específico, parece hacer referencia a los textos de los Santos Padres o a los exempla. Esta situación, más que servir de obstáculo, es la que se aprovecha para elaborar los glosarios específicos de las ingentes obras de diferentes autores.

Rimas y versos. La intención de Alprão a la hora de escribir este manual es ayudar a los discípulos que se acercan al mismo en la ardua tarea de componer homilías. Para lograr este objetivo, el franciscano no deja a un lado los procesos rítmicos y el verso como técnica de memorización. Además de esta memorización se trata de una técnica privada de la retórica propia de las composiciones de los sermones, como se ha indicado en líneas anteriores. Ya hemos indicado, también, las referencias retóricas, ligadas a las artes dictandi o dictaminis. La antigua métrica latina basada en la cantidad nos daba licencia a los traductores para ser versátiles en nuestra tarea. Sin embargo, esta forma de versificar dio paso a una métrica acentuativa basada en el acento y la rima. Este tipo de métrica nos ha obligado a tratar de transponer la rima de una lengua a otra. En este sentido, las diferentes teorías de la traducción son divergentes: desde las que opinan que la rima en la lengua de origen debe dejarse a un lado en la lengua de destino hasta las que defienden que al menos hay que intentarlo. Nosotros hemos decidido adoptar esta última opción, con los consiguientes riesgos y valoraciones positivas y negativas de quien se sirva de esta traducción. Nos hemos topado con casos en los que la rima ha podido reproducirse sin dificultad, casos en los que hemos desistido y, por último, ocasiones intermedias en las que hemos alterado el orden más lógico de las palabras en la lengua de destino. En aquellos fragmentos en los que hemos adoptado esta última opción, reconocemos que, a veces hemos obtenido resultados quizá algo abigarrados o barrocos.

Persona del discurso. En su tratado sobre la predicación, Alprão utiliza con asiduidad la segunda persona y el imperativo. Con ello logra un mayor acercamiento al lector de su doctrina. Sin embargo, nosotros hemos optado por utilizar la tercera persona -la no-persona-, el plural mayestático y la pasiva refleja. Con ello hemos pretendido sintetizar en el texto su carácter universal como método o recurso para componer homilías. El número potencial de lectores del Ars praedicandi de Alprão en el momento de su publicación era más restringido que la difusión que ahora 
tiene esta traducción. Somos conscientes de que se trata de una decisión comprometida -como todas las que se llevan a cabo en traducción-, por lo que nos sometemos a toda crítica constructiva que pueda derivarse de ello, siempre con el afán de mejorar la técnica de traducción.

Estos son sólo algunos de los problemas con los que nos hemos encontrado a la hora de traducir al franciscano Alfonso de Alprão. Ahora bien, línea a línea nos hemos topado con no pocos obstáculos que no han sido fáciles de resolver. En este sentido, todas las críticas que reciba nuestra traducción, serán tomadas como constructivas, como una lija útil en el pulimentado de la tarea de traducir el Latín Medieval, ya que los traductores tenemos siempre presente, aunque en ocasiones de forma inconsciente, aquello de traduttore, traditore, mal que nos pese. 


\begin{abstract}
ARS PRAEDICANDI ${ }^{1}$
Incipit ARS PRAEDICANDI, conferendi, collationandi, arengandi, secundum multiplicem modum, etcetera.

Dividitur iste tractatus in duas partes principales, scilicet: in prologum et processum. Circa prologum est notandum quod ars praedicandi tres habet considerationes principales. Prima consideratio est circa introductionem; secunda est circa divisione; et tertia est circa distinctionem.

Introductio sic describitur: introductio est quidam processus sive preambulum, ordinatum debite in forma et modo, ex quo formaliter vel persuasive, sive congruenter, infertur thema praeasumptum ad divinum verbum pronuntiandum. Et huius definitionis particulae patebunt in suo loco.

Divisio sic difinitur: divisio est illatio contentorum, seu annexorum partibus thematis, de cuius descriptionis particulae, etc, patebunt in suo loco.

Distinctio sic describitur: distinctio est sumptio membrorum aequivoce vel univoce sub uno vocabulo contentorum, quorum quodlibet fundamentum habet in Sacra Scriptura, vel authentica. Huius descriptionis partes patebunt suo loco, hoc est, in de prologo.
\end{abstract}

${ }^{1}$ Seguimos el texto latino en la edición de Albert G. Hauf presentado en el trabajo ya citado: "El «Ars Praedicandi» de Alfonso d'Alprão, O.F.M. Aportación al estudio de la teoría de la predicación en la Península Ibérica", en Archivum Franciscanum Historicum 72 (1979) 233-329. La edición del opúsculo ocupa las páginas 264-329. Tanto en el texto latino como en la traducción seguimos la división del texto propuesta por el editor. Añadiremos algunas notas en la traducción para clarificar o ayudar a la propia traducción española y señalaremos las citas. 


\section{ARS PRAEDICANDI}

Comienza El arte de predicar, de dar conferencias, de hacer colaciones, de arengar... de múltiples modos. Este tratado se divide en dos partes principales, esto es: prólogo y desarrollo. Sobre el prólogo hay que señalar que El arte de predicar contiene tres reflexiones principales: la primera trata acerca de la introducción, la segunda acerca de la división y la tercera acerca de la distinción.

Describimos la introducción de la siguiente manera: es un cierto proceso o preámbulo, ordenado como es debido tanto en la forma como en el modo, a partir del cual se infiere, de un modo formal, persuasivo o conveniente el tema que se pretende tratar al pronunciar el discurso divino. Las particularidades de esta definición se tratarán en su momento.

Definimos la división de la siguiente manera: es la ligazón de los contenidos, de las conexiones con las partes del tema. Las particularidades de todo esto serán tratadas en su momento.

Describimos la distinción de la siguiente manera: se trata bien de la suma equivoca de los miembros, bien de la suma univoca bajo una sola palabra de los contenidos cuyo fundamento quodlibético está en la Sagrada Escritura, es decir, la auténtica. Las partes de esta descripción se tratarán en su lugar, esto es, donde se trata del prólogo. 
[I.1] Sequitur PRIMUM CAPITUlum, QUOD DiCITUR DE INTRODUCIONE SERMONIS

Circa introductionem, ista sunt consideranda: primo, quid sit thema; $2^{\circ}$, de conditionibus thematis; tertio, de speciebus eius et modis introducendi.

Circa primum, est sapiendum quod thema sic describitur: thema sermonis seu collationis est oratio, vel aequivalens, sumpta de Sacra Scriptura, fundamentaliter ad eruditionem populi sive laudem Dei, et virtutum vitiorumque reprehensionem applicabilis, vel ad laudem alicuius personae, sive actus, sive scientiae. Hoc intendit dicere Strattioliton, qui definit thema dicens: "Thema est materia dictatorum, id est materiale fundamentum dictatoris" ${ }^{1}$. Et dictatos sumitur hic pro oratore.

\section{[I.2] Sequitur de conditionibus thematis}

De thematis descriptione. Secundum praemissum superius, de eius conditionibus est dicendum. Est, igitur, prima conditio, quod thema debet esse compositum. Hoc patet per hoc quod in sua descriptione dicitur, quod "est oratio vel aequivalens" componi, tu verbum primae personae vel secundae, vel sicut una vox et (216b) similia. Etiam, quia thema habet dividi, et si non compositum, dividi non potest.

Secunda conditio est: quod debet esse de corpore Bibliae. Et hoc patet per illud quod ponitur in descriptione cum dicitur: "de Sacra Scriptura", quia Biblia, vel corpus Bibliae, dicitur anthonomatice, id est, per excellentiam Sacrae Scripturae.

Tertia conditio, quod debet esse verbum primum, verbum iniciativum totius sermonis. Quod patet in illa particula quae dicit: "fundamentaliter".

Quarta conditio est: quod sit iuxta materiam tractandam. Hoc patet per illam particulam quae dicit: "ad eruditionem populi".

Quinta conditio est: quod sit fructuosus, et ex omnibus terminis compositum, et verbo indicativo. Et hoc patet per residuum descriptionis in ipso, quia debet ad multa applicari. Et hoc de secundo praemisso.

${ }^{1}$ Albert G. Hauf señala que esta definición coincide conceptualmente con la de Alain de Lille en su De arte praedicatoria en PL, 210, 111 (PL: Patrologiae Cursus completus. Series latina, 221 vols., ed. de Migne, apud Garnier fratres, Paris 1844-1855, con índices 1862-1865). The Art of Preaching, trad. al inglés, G. Evans, Cistercian Publications, Kalamazoo 1981. 


\section{[I.1] CAPÍTULO I. SOBRE LA INTRODUCCIÓN DEL SERMÓN}

En torno a la introducción, estas son las cosas que hay que considerar: en primer lugar qué es el tema; en segundo lugar las condiciones del tema; en tercer lugar sus especies y los modos de introducirlas.

En cuanto a lo primero, es sabido que el tema se define de la siguiente manera: es una alocución del sermón o de la colación, o algo equivalente, tomada de la Sagrada Escritura, que sirve como fundamento para instrucción del pueblo o para la gloria de Dios, y es además aplicable a las virtudes y a la reprehensión de los vicios. También sirve para alabanza de alguna persona, acto o conocimiento. Esto es lo que trata de decir Strattioliton, quien lo define diciendo: "el tema es el material de trabajo de los dictatores, es decir, el fundamento material del dictator" el cual compone los dictatos de acuerdo con el orador.

\section{[I.2] Sobre las condiciones del tema}

En torno a la descripción del tema. Según la premisa anterior, se ha de hablar sobre las condiciones del tema. La primera condición es que el tema debe estar compuesto. Esto se explica por medio de lo que se dijo en su definición: "es una alocución [...] o algo equivalente", es decir un verbo en primera o segunda persona, una voz o cosas (216b) similares. Además, puesto que el tema tiene que ser dividido, en el caso de que no fuera una secuencia compuesta, no podría ser dividido.

La segunda condición es que debe estar tomado del cuerpo de la Biblia. Esto se explica gracias a lo expuesto en la descripción cuando se decía: "en la Sagrada Escritura", ya que "Biblia" o "cuerpo de la Biblia" se dice por antonomasia para referirse por excelencia a las Sagradas Escrituras.

La tercera condición es que tiene que tener una primera palabra que sirva para iniciar todo el sermón. Esto queda expuesto en aquella parte que dice: "como fundamento".

La cuarta condición es que tenga que ver con la materia que ha de tratarse. Esto queda patente en aquella parte que dice: "para instrucción del pueblo".

La quinta condición es que sea fructífero, que esté compuesto a partir de todos los términos y que cotenga una palabra señalada. Esto queda claro gracias al resto de la misma definición la cual debe aplicarse a multitud de cosas. Esto es lo que había que decir acerca de la segunda premisa. 


\section{[I.3] De notabilibus quibus utendum est, et tota ista arte}

Primum notabile est quod omnis auctoritas sumpta de Sacra Scriptura motive probationis, in sensu uti. Tu quando dicimus: Beati pacifici, quoniam filii Dei vocabuntur ${ }^{1}$, etc, idem quasi dicet: omnes pacifici dicuntur beati, omnes pacifici dicuntur filii Dei.

Secundum notabile: quod auctoritas sumpta concorditer ad thema est in triplici concordantia. Nam quaedam dicuntur realiter concordes themati, quaedam vocaliter concordes themati, quaedam vocaliter et realiter concordes in simul.

Realiter concordes themati sunt quae non consonant in vocabulo propter quod adducuntur, sed bene in significatione, ut "vincere" et "triumphare". Et omnia synonima sunt huiusmodi.

Vocaliter concordes sunt quae in voce consonant sed in significatione non, tu: Fecit Deus hominem ad imaginem, etc, et: Ista verumtamen in imagine pertransibit homo ${ }^{2}$. Hic est magna consonantia vocabulorum et maior dissonantia in significatione et, breviter, hoc accidit inter omnia vocabula contituentia aliquam distinctionem.

Realiter et vocaliter concordes in summa, sunt quae habent consonantiam consimilem in voce et in significatione, seu summam, ut: Dedit eis potestatem super omnia daemonia, et: Dedit potestatem ut vexatos a daemonibus liberartent, si talia reperiuntur in Sacra Scriptura, etc. ${ }^{3}$.

\section{[I.4] Rubrica de modis et speciebus introducendi}

Circa modos introducendi est notandum quod decem sunt modi principales introducendi seu introductionis, scilicet: per syllogismum, per consequentiam, per inductionem, (216 v.a) per exemplum, per originale, per auctoritatem philosopharum, per divisionem, per distinctionem, per figuram, per quaestionem, etc.

${ }^{1}$ Mt 5,9. Cf. Biblia Sacra. Iyuxta vulgatam versionem, $4^{\mathrm{a}}$ ed. rev. Deutsche Bibelgesellschft, Stuttgart 1994.

${ }^{2}$ Gn 1,26: "et ait faciamus hominem ad imaginem et similitudinem nostram..."; Ps 38,7 (Iuxta LXX): "veruntamem in imagine pertransit homo...".

${ }^{3}$ Lc 9,1: "Convocatis autem duodecim apostolis dedit illis virtutem et potestatem super omnia daemonia...”. La segunda cita, señala A. G. Hauf, parece creación del autor. Siendo así parece tener su origen en la acción taumatúrgica de Jesús en Mc 1,34: "et curavit multos que vexabantur variis languoribus et daemonia multa eiciebat"; y en la de los discípulos de Jesús que aparece en Mc 3,15: "et dedit illis potestatem curandi infirmitates et eiciendi demonia". Estas dos citas forman parte del argumentario teológico, lo que hace pensar que es una cita compuesta realizada por él mismo. 
[I.3] Sobre los presupuestos que hay que utilizar en todo este arte

El primero es que toda autoridad tomada de la Sagrada Escritura a modo de prueba, se usa como un razonamiento, como cuando decimos: "bienaventurados los pacificos, porque ellos serán llamados hijos de Dios", que es igual que si dijéramos: todos los pacíficos son llamados bienaventurados, y todos los que trabajan por la paz son llamados hijos de Dios.

El segundo presupuesto importante es que la autoridad asumida ha de estar de acuerdo con el tema según una triple concordancia. Así, ciertas cosas concuerdan con el tema de manera real, otras de forma vocálica y, otras, simultáneamente, de manera real y de forma vocálica.

Concuerdan de manera real con el tema aquellas que no coinciden en el vocablo del que se hace uso sino más bien en el significado, tal como "vencer" y "triunfar". Todos los sinónimos son de este tipo.

Las que concuerdan de forma vocálica son aquellas que coinciden en el significante, pero no en el significado como: "Dios hizo al hombre a su imagen, etc..." y "sin embargo el hombre pasa como una imagen". Estos ejemplos tienen una gran consonancia en cuanto a las palabras, pero aun una mayor disonancia en cuanto al significado. En resumen, esto sucede en todas las palabras que contienen alguna distinción.

Concuerdan de manera real y de forma vocálica aquellas que tienen a la vez una conformidad o suma tanto en el significante como en el significado, tal como sucede en: "les dio poder sobre todos los demonios, y les dio poder para liberar a aquellos a los que los demonios ultrajan", si tales cosas están presentes en la Sagrada Escritura.

\section{[I.4] Comentario sobre los modos y las clases de introducción}

Acerca de los modos de la introducción hay que decir que son diez las principales formas de introducir, es decir, de introducción. A saber: por medio de un silogismo, de una consecuencia, por inducción, (216 v.a) por medio de un ejemplo, de un original, por medio de la autoridad de los filósofos, por división, por distinción, por medio de una figura, por medio de una pregunta, etc. 


\section{[I.4.I.I] Capitulum de introductione per syllogismum}

Introductio autem per syllogismum sic fit: iuxta principalem terminum thematis, scilicet, habere est tres auctoritates Sacrae Scripturae in quibus simile praedicatum principale dicatur de aliquo subiecto propter varias causas. Et iuxta summam istarum trium auctoritatum formentur tres rythmi concordes, in forma subiecti sumendi, et totum thema concorditer in rythmis ad praecedencia sumatur pro praedicato, vel principalior pars thematis a parte praedicati, et totum illud praedicatum coniunctum, simul ordinatum, est una propositio maior.

Probatio autem illius maioris debet sic fieri: secundum quod sunt tres partes a parte subiecti, quaelibet illarum sumpta cum themate, vel cum pricipaliori parte thematis, debet probari per auctoritatem Sacrae Scripturae, unde habuit radicem et ortum. Ex quibus sequitur quod, licet maior sit una propositio decopulato subiecto, tamen in sua probatione probatur ad modum copulativae compositae ex tribus propositionibus integris.

\section{[I.4.I.2] Regulae servietes maiori propositioni}

Prima est: quod maior propositio debet probari succincte absque originale vel originalibus et solum quodlibet membrum debet probari per unam auctoritatem Sacrae Scripturae.

Secunda regula est: quod si forte thema non poterit duci ad concordiam rhythmice tu, baculis positis, a parte subiecti fiat sibi quidam rhythmus conveniens, cum quo consonanter concordet. Et hoc de maiori.

Minor autem sic ordinatur: sumatur in subiectum illud de quo praedicare vis, et omne illud quod ponebatur a parte subiecti in maiori, ponatur a parte praedicati in minori mediante verbo convenienti, sub eisdem verbis vel aequivalentibus, pulchris et in rhythmice, quorum quaelibet pars debet probari per se, auctoritatibus covenientibus ad membra.

Regula minoris propositionis: in minori propositione sermo vel collatio potest dilatari, eo quod sub quolibet membro potest aptari distinctio, vel applicari originale, et, similiter, originalia et pars historiae sanctorum, si fuerit sermo de eorum. Immo in tantum potest dilatari, quod sola introductio sufficiat pro sermone, tu tempore fit moderno.

Modus concluendi est quod resumatur in simul maior et minor, quasi fias argumentum, et tunc inferatur thema pro conclusione. 


\section{[I.4.I.I] Introducción por silogismo}

La introducción por silogismo se hace de la siguiente manera: junto al principal término del tema tiene que haber tres autoridades de la Sagrada Escritura en las que un mismo predicado principal hable de algún sujeto por varias causas diferentes. Junto a estas tres autoridades han de formarse tres rimas en concordancia que se admitan bajo la forma de un sujeto que ha de ser tomado como premisa. Y todo el tema, con idéntico ritmo, se adjunta a lo precedente por medio del predicado, o bien se suma la parte más principal del tema a la parte del predicado. Todo aquel predicado unido o, lo que es lo mismo, ordenado constituye la premisa mayor.

La comprobación de dicha premisa mayor debe hacerse del siguiente modo: en la medida en que son tres las partes del sujeto, cualquiera de ellas, relacionada con el tema o con la parte principal del tema, debe probarse por la autoridad de la Sagrada Escritura donde tiene su raíz y nacimiento. A partir de aquí se deduce que es posible que la mayor sea una sola proposición con un sujeto sin cópula, si bien en su comprobación, se prueba a la manera de una proposición copulativa compuesta a partir de tres proposiciones integras.

\section{[I.4.1.2] Reglas que sirven para la premisa mayor}

La primera es que la premisa mayor debe probarse de forma sucinta, sin el original u originales ${ }^{1}$, y que cualquier miembro por si solo debe probarse por medio de una sola autoridad de la Sagrada Escritura.

La segunda regla es que si aconteciera que el tema no puede ser construido de acuerdo con una rima, entonces, teniendo en cuenta los apoyos, ha de formarse de una parte del sujeto una rima adecuada, con la cual esté en consonancia. Esto sobre la mayor.

La premisa menor se organiza sin embargo de la siguiente manera: se incluye en el sujeto aquello de lo que quieras predicar y todo aquello que se ponía en la parte del sujeto en la mayor, ha de colocarse en la parte del predicado de la menor mediante una palabra adecuada o mediante las mismas palabras o equivalentes, hermosas y rimadas. Cualquiera de sus partes, ha de poder ser demostrada por sí misma, con autoridades adecuadas a sus miembros.

La regla de la premisa menor es la siguiente: en la premisa menor, el sermón o la colación pueden ampliarse, ya que bajo cualquier miembro puede acomodarse una distinción, agregarse un original, unos los originales o bien una parte de la historia de los santos, en el caso de que el sermón trate acerca de estos. De hecho, la premisa puede ser ampliada hasta tal punto que la sola introducción baste en lugar del sermón, tal y como se hace en los tiempos modernos.

La manera de concluir consiste, lo mismo en la mayor como en la menor, en resumir como si estuvieses construyendo un argumento. Se vuelve entonces a citar el tema a modo de conclusión.

${ }^{1}$ N.T. Referencia al texto o metáfora original. 
[I.4.I.3] Exemplar omnium dictorum datur hic in practica. Sumatur istud thema ad honorem Virginis pro sua Assumptione: "In capite eius corona", (Apoc. $12,[1])^{1}$. Si bene inspiciatur istud thema, reperitur quod in eodem servantur omnes conditiones aliter dictae in themate servandae, cuius applicationem lectori commendo.

Ut autem istud thema introducatur per syllogismum, iuxta regulam superius datam, reperiuntur tres auctoritates in Sacra Scriptura in quibus est istud vocabulum: "corona", quod est principalior pars thematis a parte praedicati. Quae auctoritates denotant varias causas propter quas aliquid dicitur dicitur coronari. Una denotat sapientiam pro causa; alia denotat multiplicationem generationis pro causa; alia denotat diligentem vigilantiam super subditos pro causa. Quae auctoritates patebunt expresse in suo loco.

Iuxta quarum auctoritatum summam, formatur una maior propositio isto modo: ut nostrum thema faciliter concludatur, talis maior propositio proponatur.

\begin{tabular}{|c|c|c|}
\hline \multirow{3}{*}{ "Quaelibet creatura" } & $\begin{array}{l}\text { Quae superno infuso numine, est } \\
\text { compta sapientia }\end{array}$ & \multirow{3}{*}{$\begin{array}{l}\text { corona ornatur in culmine capitis, } \\
\text { decentia vel affluentia". }\end{array}$} \\
\hline & $\begin{array}{l}\text { Quae lato copioso germine, est } \\
\text { fulta abundantia }\end{array}$ & \\
\hline & $\begin{array}{l}\text { Quae super gratioso agmine est } \\
\text { vigil diligentia }\end{array}$ & \\
\hline
\end{tabular}

Ecce vides maiorem propositionem formatam experte, cuius subiecti sunt tres baculi correspondentes in summam tribus auctoritatibus dicendis, et experte praedicati ponatur thema concorditer et rhythmice ad tres baculos. Sed ubi hoc fieri non poterit, fiat sicut dictum est alias, id est: fiat rhythmus unus seorsum, cum quo thema concordat, sicut si diceretur sic:

$$
\begin{aligned}
& \text { "Iuste in capite adornatur } \\
& \text { pulchra corona, et ornatur". }
\end{aligned}
$$

${ }^{1}$ Apc 12,1: "et signum paruit in caelo mulier amicta sole et luna sub pedibus eius et in capite eius corona stellarum duodecim". 
[I.4.I.3] A continuación se da un ejemplo práctico de todo lo dicho. El siguiente tema se toma en honor de la Asunción de la Virgen: En su cabeza una corona $\left(\right.$ Apc 12,1) ${ }^{1}$. Si se examina con atención este tema, se descubre que en él se mantienen todas las condiciones anteriormente dichas, que han de ser observadas en el tema y cuya aplicación encomiendo al lector.

Para introducir este tema por silogismo, teniendo en cuenta la regla dada más arriba, encontramos tres autoridades en la Sagrada Escritura en las cuales está el vocablo "corona" que es la parte principal del predicado del tema de la parte del predicado. Estas autoridades indican varias causas por las cuales se puede decir que alguien es coronado; una señala que por causa de la sabiduría; otra denota que por causa de la proliferación de la estirpe; otra que por causa de la diligente vigilancia sobre los súbditos. Estas autoridades serán tratadas expresamente en su lugar.

A partir de la suma de estas autoridades, se forma una premisa mayor del modo siguiente: para que nuestro tema pueda concluirse fácilmente, se ha de proponer una premisa mayor semejante a esta:

\begin{tabular}{|c|c|c|}
\hline \multirow{3}{*}{ Cualquier criatura } & $\begin{array}{l}\text {...que, recibida la inspiración } \\
\text { suprema, queda adornada con la } \\
\text { sabiduría... }\end{array}$ & \multirow{3}{*}{$\begin{array}{l}\text { ha de ser honrada con la corona } \\
\text { en lo más alto de la cabeza bien } \\
\text { por gracia bien por plenitud. }\end{array}$} \\
\hline & $\begin{array}{l}\text {...que, tras recibir amplio y } \\
\text { copioso germen, está sostenida } \\
\text { en la abundancia... }\end{array}$ & \\
\hline & $\begin{array}{l}\text {... que mantiene una vigilancia } \\
\text { diligente sobre una multitud } \\
\text { amada... }\end{array}$ & \\
\hline
\end{tabular}

Aquí puedes ver una premisa mayor construida de forma experimentada, cuyos sujetos son tres apoyos que corresponden en suma a las tres autoridades que han de ser citadas. Si uno es experto también será capaz de establecer el tema del predicado de manera que rime y concuerde con los tres apoyos. Pero donde esto no puede llevarse a cabo, se ha de proceder como se ha dicho en otro momento, es decir: se ha de establecer independientemente una sola rima que concuerde con el tema, como si se dijera así:

\section{"Con una hermosa corona en la cabeza,} es adornada y honrada"

$1 N$. T. En el texto latino mantenemos la abreviatura del libro bíblico que aparece en la edición de Albert G. Hauf. En la traducción española las abrevitaruas de la edición de la Vulgata que seguimos. 
Probabis autem, sic: dixi, primo, quod.

"persona quae superno infuso numine est compta sapientia, corona ornatur in culmine capitis affluentia".

Hoc probatur per sapientem, (Prov. 4, [5-9]) dicentem: Posside sapientiam, et in omni possessione tua adquire prudentiam. Arripe illam, et exaltabit te, et glorificaberis ab ea cum eam fueris ampexatus dabit (217a) capiti tuo augmenta gratiarum, et corona inclita proteget te ${ }^{l}$. Et hoc de prima parte maioris, etc.

Dixi, $2^{\circ}$, in eadem maiori:

"Quaelibet creatura que lato copioso germine est fulta abundancia, corona ornatur in culmine capitis decentia".

Hoc probatur auctoritate sapientis dicentis: Corona senum, filii filiorum, et gloria filiorum, patres eorum. (Prov. 17 capitulo 6). Et hoc de secunda parte maioris.

Dixi, tertio in eadem maiori:

"Quaelibet creatura quae super gratioso agmine est vigil diligentia, corona ornatur in culmine capitis decentia".

Probatur auctoritate eiusdem sapientis dicentis: Diligenter agnosce vultum pecoris tui, tuosque greges considera: Non enim habebis iugiter potestatem. Sed corona tribuetur tibi in generationem et generationem (Prov. $2^{\text {o2 }}$ ). Et hoc de tertia parte maioris et, per consequentiam, de tota maiore, quam, brevitati causa, non resumo hic.

Si bene advertas, videbis quomodo istae tres auctoritates ad probationem maioris inductae, ad duo tibi serviunt: primo, administrant tibi summam, ex qua formas tibi baculos et propositiones; $2^{\circ}$, probant tibi qualem partem maioris, ut satis patuit in exemplari. Item, hic videbis quomodo succinte et breviter probatur maior propositio absque prolixitate auctoritatum, iuxta regulam superius datam. Et hoc de exemplari maioris cum tota doctrina, etc.

${ }^{1}$ Prv 4,5-9: "5 posside sapientiam posside prudentiam ne obliscaris neque declines a verbis oris mei ${ }^{6}$ be dimittas eam et custociet te dirige eam et servabit te ${ }^{7}$ principium sapientiae posside sapientiam et in omni possessione tua adquire prudentiam ${ }^{8}$ arripe illam et exaltabit te glorificaberis ab ea cum eam fueris amplexatus ${ }^{9}$ dabit capiti tuo augmenta gratiarum et corona ínclita proteget te".

$2 \operatorname{Prv} 27,23-24$. 
Esto se prueba de la siguiente manera.

Dije en primer lugar que:

"Cualquier persona que, recibida la inspiración suprema, queda adornada con la sabiduría, ha de ser honrada con la corona en lo más alto de la cabeza por plenitud"

Esto se puede verificar por medio del sabio que dice en Prv 4,5-9: Adquiere la sabiduría, a costa de todos tus bienes adquiere prudencia. Haz acopio de ella y ella te ensalzara; ella te honrará si tú la abrazas; pondrá (217a) en tu cabeza una diadema de gracia, una espléndida corona será tu regalo. Y esto sobre la primera parte de la mayor.

En la misma mayor dije en segundo lugar:

"Cualquier criatura que, tras recibir un copioso germen está sostenida en la abundancia, ha de ser honrada con la corona en lo más alto de la cabeza por gracia"

Esto se puede verificar por medio del sabio cuando dice en Prv 17.6: Corona de los ancianos son los hijos de los hijos; los padres son el honor de los hijos. $\mathrm{Y}$ esto sobre la segunda parte de la mayor.

En la misma premisa mayor dije en tercer lugar:

"Cualquier criatura que mantiene una vigilancia diligente sobre una multitud amada, ha de ser honrada con la corona en lo más alto de la cabeza por gracia”.

Esto se puede verificar por medio del sabio cuando dice en Prv $2^{\circ}$ : Sé diligente en conocer el estado de tus ovejas, aplica tu corazón a tu rebaño; porque no es eterna la riqueza, pero la corona se transmite de generación en generación. Y esto sobre la tercera parte de la mayor, y en consecuencia sobre toda la premisa, la cual, para ser breve, no resumo aquí.

Si te fijas bien, verás de qué modo estas tres autoridades presentadas para la premisa mayor, te pueden servir de dos maneras. En primer lugar te llevan a la conclusión, a partir de la cual se forman los apoyos y las proposiciones. En segundo lugar, prueban una parte determinada de la premisa mayor, tal y como se ha explicado suficientemente en el ejemplo. De igual modo podrás ver aquí de qué forma se comprueba, sucinta y brevemente, una premisa mayor, sin la prolijidad de las autoridades, según la regla dada más arriba. Y esto acerca del ejemplo de la mayor, una vez aplicada toda la doctrina. 


\section{[I.4.I.4] Sequitur nunc de exemplari minoris}

Primo, notandum est quod ideo dilatatio sermonis debet fieri in minori quia ibi exprimitur intentio praedicantis per applicationem materiae ad subiectum de quo fit sermo.

Secundo, notandum quod sub maiori praelibata potest ordinari dupliciter minor. Primo, applicando baculos ipsi Virgini praedictos, sic dicendo: si volumus inspicere Virginem, et gloriosam vitam Virginis Matris, reperiemus quod ipsa Virgo:

"Superno infuso numine fuit compta sapientia.

Lato et copioso germine fuit fulta abundantia.

Super gratioso agmine fuit vigil diligentia, etc".

Sed hoc fit ut evitetur labor, sed pulchrius fit et artificiosius, si eadem minor in verbis aequivalentibus et synonyma formaretur, ut si dicatur sic: si devote contemplemus spiramentum vitae Virginis usque ad egressum de hoc saeculo, reperiemus

\begin{tabular}{|l|l|l|l|}
\hline \multirow{4}{*}{ Quod } & "Sapiens, prudens radiavit & \multirow{4}{*}{} & perlustrata sapientia \\
\cline { 2 - 2 } & Propaginibus abundavit & & circumdata abundantia \\
\cline { 2 - 2 } & Super commissos vigilavit & & affectata diligentia, etc." \\
\hline
\end{tabular}

Et habes duplicem modum formandi minorem.

\section{[I.4.I.5] Nunc sequitur de modo praedicandi et dilatandi minorem}

Dixi, primo, quod si contemplemus spiramentum Vitae Virginis, etc, reperiemus quod "sapiens, prudens radiavit ut perlustrata sapientia". Ad cuius primae partis minoris probationem est notandum quod tribus modis efficitur vel cognoscitur quis sapiens. Hoc quidem probabitur, et, primo: "Audiendo firma attentione".

$2^{\circ}$ : "Custodiendo interna retentione".

$3^{\circ}$ : "Impartendo superna, vel firma, devotione, vel affectione". 


\section{[I.4.1.4] Ejemplo de la premisa menor}

En primer lugar hay que saber que la ampliación del sermón debe realizarse en la premisa menor, ya que allí es donde se expresa la intención del predicador por medio de la aplicación de la materia al sujeto sobre el cual se hace el sermón.

En segundo lugar hay que saber que bajo la premisa mayor examinada antes, la menor puede ser organizada de dos maneras. La primera consiste en aplicar los apoyos anteriormente dichos a la Virgen misma, diciendo lo siguiente: si queremos prestar atención a la Virgen y a la gloriosa vida de la Virgen Madre, encontraremos que la Virgen misma...

"Recibida la inspiración suprema, quedó adornada con la sabiduría.

Tras recibir amplio y copioso germen, estuvo sostenida en la abundancia. Mantuvo una vigilancia diligente sobre la multitud amada, etc..."

Se procede de este modo para no esforzarse. Sin embargo esta tarea puede llevarse a cabo de forma más hermosa y artificiosa si la misma premisa menor se forma con palabras equivalentes o sinónimas, como si se dijese así: si contempláramos devotamente el espíritu de la vida de la Virgen desde su llegada al siglo hasta su partida de él, descubriríamos que la Virgen...

\begin{tabular}{|l|l|l|}
\hline Brilló sabia y prudente & \multirow{4}{*}{ como } & santificada por la sabiduría. \\
\cline { 1 - 1 } Tuvo una descendencia abundante & rodeada de generosidad. \\
\cline { 1 - 1 } Vigiló a los que le fueron confiados & & movida por la diligencia \\
\hline
\end{tabular}

Tienes, por tanto, dos maneras de formar la menor.

\section{[I.4.1.5] Sobre el modo de predicar y ampliar la menor}

Dije en primer lugar que si contempláramos el espíritu de la vida de la Virgen etc... descubriríamos que "brilló sabia y prudente como santificada por la sabiduría". Para la comprobación de esta primera parte de la menores necesario saber que hay tres maneras de proceder, es decir, de conocer quién es tenido por sabio. Esto ciertamente puede probarse...

en primer lugar: "escuchando con firme atención".

en segundo lugar: "custodiando con interna retención".

en tercer lugar: "comunicando con suprema y firme devoción y afección" 
Pro primo, occurrit illud quod scribitur Prov. $1^{\circ}$ capitulo, 5: audiens sapiens sapientior erit. Pro secundo, occurrit illud quod scribitur Prov. $2^{\circ}$ capitulo, [10-11]: si intraverit sapientia cor tuum, et consilium custodiet te ${ }^{1}$. Et infra, scilicet: cor prudentis possidebit sapientiam, et auris sapientium quaerit doctrinam. Pro tertio, occurrit illud Prov. 10, [31]: os iusti parturi[e]t sapientiam. Et infra, capitulo 20, [29]: sapiens in verbis producit se ipsum, et homo prudens placebit magnatis $^{2}$.

Applicando igitur, et exponendo sapientiam Virginis gloriosae per quaelibet istarum pedum distinctionis, satis liquet et clare, per quamdam fantasiam et speculationem, quod Virgo gloriosa primo fuit visa sapiens "audiendo firma attentione". Quae speculatio est ista: reperio triplicem scholam in qua Virgo demonstratur attente audivisse:

\begin{tabular}{|l|l|l|}
\hline Prima & \multirow{3}{*}{ schola est } & "Visceralis maternitatis". \\
\cline { 1 - 1 } Secunda & "Parentalis sedulitatis". \\
\cline { 3 - 3 } Tertia & & "Spiritalis radietatis". \\
\hline
\end{tabular}

\begin{tabular}{|c|c|c|}
\hline In prima & \multirow{3}{*}{ schola fuit } & "Prima lectio a tota Trinitate, puritatis et munditiae". \\
\hline In secunda & & "Secunda lectio ab utroque parente, quae fuit sanctitatis et iustitiae" \\
\hline In tertia & & "Tertia lectio, a Spiritu Sancto, quae fuit claritatis et notitiae". \\
\hline
\end{tabular}

Circa primam scholam, quae dicitur "visceralis maternitatis", et primam lectionem, quae est "munditiae et puritatis", est speculandum quod in alvo casto materno animae matris Virginis gloriosae Mariae, dum tota Trinitas animam Virginis (217 v.a) crearet, sunt ista verba totius Trinitatis, per modum magistri ad ipsam tamquam discipulam: audi, filia, et vide, et inclina aurem tuam (Ps. 44, 11). Quoniam: cor sapientis intelligitur in sapientia. Et auris bona audiet cum omni concupiscentia sapientiam (Eccli. $3^{\circ}$, [31]). Nam in malevolam animam non introibit sapienia, nec habitabit in corpore subdito peccatis (Sap. 1, [4]). Cum, igitur, mihi sis futura domus, in que sapientia vitae ut in habitaculo argenteo habitet, ideo decrevi ut tota sis pulchra, amica mea, et macula nulla non sit in te (Cant. 4, [7]).

1 Prv 18,15.

2 Sir 20,29: "VERBUM PARABOLARUM. Sapiens in verbis producet se ipsum et homo prudens placebit magnatis". 
En cuanto a lo primero sucede aquello que aparece escrito en Prv. 1,5: Que escuche el sabio y será aun más sabio. En cuanto a lo segundo sucede lo escrito en Prov. 2,10-11: Cuando entre la sabiduría en tu corazón, la prudencia te custodiará. Y más abajo: El corazón prudente, poseerá la sabiduría, y el oído de los sabios buscará la doctrina. En cuanto a lo tercero sucede lo escrito en Prov. 10,31: la boca del justo engendra sabiduría. Y más abajo en 20,29: El sabio se realiza a si mismo en sus palabras y el hombre prudente complace a los poderosos.

Así pues, aplicando y exponiendo la sabiduría de la gloriosa Virgen por medio de cualquiera de estos modos de distinción, se demuestra suficiente y claramente, a través de cierta imaginación y especulación, que la Virgen gloriosa fue en primer lugar reconocida como sabia porque "escuchaba con firme atención". Tal especulación nace de lo siguiente: encontramos una triple escuela en la cual se demuestra que la Virgen escuchó atentamente:

\begin{tabular}{|l|l|l|}
\hline La primera & \multirow{2}{*}{...escuela es... } & La maternidad propia de las entrañas. \\
\cline { 1 - 1 } La segunda & & El celo propio de los padres. \\
\cline { 1 - 1 } La tercera & & El esplendor del Espíritu. \\
\hline
\end{tabular}

\begin{tabular}{|c|c|c|}
\hline En la primera & \multirow{3}{*}{...escuela tuvo lugar... } & $\begin{array}{l}\text { La primera lección de pureza y pulcritud, de mano } \\
\text { de toda la Trinidad. }\end{array}$ \\
\hline En la segunda & & $\begin{array}{l}\text { La segunda lección, que trató acerca de la santidad } \\
\text { y la justicia, de mano de sus padres. }\end{array}$ \\
\hline En la tercera & & $\begin{array}{l}\text { La tercera lección, que trató de la claridad y el } \\
\text { conocimiento, de mano del Espíritu Santo. }\end{array}$ \\
\hline
\end{tabular}

Acerca de la primera escuela, que habla de "la maternidad propia de sus entrañas" y acerca de la primera lección, que trata "de pulcritud y pureza", hay que pensar que en el casto vientre materno, el alma de la madre de la gloriosa Virgen María, mientras toda la Trinidad creaba el alma de la Virgen, ya guardaba estas palabras, como si un maestro se las trasmitiera a ella misma como su discípula: Escucha, hija, y mira, inclina tu oído (Ps 44,11). Puesto que el corazón del sabio medita en la sabiduría y a ella el buen oído presta atención con todo deseo (Sir 3,31). Pues en el alma malévola no entrará la sabiduría, ni habitará en un cuerpo sometido a los pecados (Sap 1,4). Así pues, al ser mi futura morada, en la cual habitase la sabiduría de la vida, determiné que toda tú fueses hermosa, amiga mía, y que ninguna mancha hubiera en ti (Ct 4,7). 
Expone ad placitum de macula originali, quare lectio sit tibi et doctrina ut diligas munditiam et puritatem, quoniam qui diligit cordis munditiam, propter gratiam labiorum suorum habebit amicum regem (Prov. 22, [11]). Cui lectioni respondet humiliter Virgo: audiam quid loquatur in me Dominus Deus (Ps. 84, [9]). Et hoc de lectione "puritatis et munditiae".

Quam scholam exiens Virgo per partum, iuris ad huius saeculi lucem apparuit inter gentes pulchra, docta, sapiens. Cuius cor et cogitatio virtutum cumulationem feliciori pulchritudine adornabat, et hoc in habitu vel in propinqua dispositione, dicente Ambrosio, in Sermone Nativitatis Virginis: "depromebant virtutes in cogitatione et affectu cordis eius inimitabilem harmoniam, quam ipsam creatix et inhibitatrix eius Dei sapientia delectabatur, coruscabant foris in superficie sermonis et actus. Verum, merito possunt homines dominum glorificare et exempla salutis accipere"". Haec ille.

Intellige originale, quia licet cum originali vel sine originali culpa concepta, ex eo quod ponitur santificata in utero, credendum est simul cum gratia sanctificationis infusas esse habituales virtutes theologales, multa alia ratione privilegi singularis, ut tam venusta quam decora in conspectu hominum apparet.

De eius sapientia mirabantur et dicebat alter ad alteram: non est talis mulier nata super terram in aspectu et pulchritudine et sapientia, et sensu verborum (Iudith 11, [19]) $)^{2}$.

Et hoc de prima parte considerationis, seu de prima sacra "visceralis maternitatis" et de prima lectione quae est "puritatis et munditiae".

Circa secundam scholam, quae erat "parentalis (217 v.b) sedulitatis", in qua fuit $2^{\circ}$ lectio scilicet: "sanctitatis et iustitiae", est speculandum quod, posita Virgine in solita educatione parentuum, iidem parentes, uno corde concordes per modum unius magistri, talem dicebant lectionem legere: audi filia, tacens reverenter, et pro reverentia accedet tibi bona gratia (Eccli 32, [9]). Audi, filia, et bene erit (Prov. 34) ${ }^{3}$. Confusio patris et matris est de filio indisciplinato; filia autem fatua in deminoratione fiet, filia autem, prudens haereditas viro suo; nam quae confundit, in contumeliam fit genitoris. Patrem et virum confundit audax, et ab impiis non minorabitur et ab utrisque inhonorabitur (Eccli. 22, [3-5]).

${ }^{1}$ Este sermón no se encuetra en los Sermones S. Ambrosio Hactenus Ascripti (PL 17, 603-734).

${ }^{2}$ Idt 11,19: "non est talis mulier super terram in aspectum in pulcritudine et in sensu verborum".

${ }^{3}$ Señala Albert G. Hauf: "No se halla, salvo error, en el lugar indicado. Se trata, más bien, de una adaptación de Ier. 38, 20, o de la invocación anterior seguida de un fragmento del Ps. 127, 2:...et bene tibi erit". Ier 38,20: "respondit autem Hieremias non te tradent audi quaeso vocem Domini quam ero loquor ad te et bene tibi erit et vivet anima tua". Ps 127,2: "[iuxta LXX] labores manuum tuarum quia: manducabis beatus est et bene tibi erit; [iuxta hebr.] laborem manuum tuarum cum comederis beatus tu et bene tibi erit". La cita bíblica Beata erit tibi erit se había convertido, a su vez, en una f'romula ocmún de saludo y la podmeos ver en algunas epístolas. Por ejemplo la podemos ver en la carta que Elisabeth de Schoenau dirije a Hidegarda de Bingen "Congratulare mecum domina.... Beata es et bene tibi erit semper, et organum spiritus saneti tu es, quia verba tua accenderunt me quasi flamma tetigisset cor meum et prorupi in hec verba" (Die Visionen der hl. Elisabeth und die Schriften der Aebte Ekbert und Emecho von Schönau, ed. F.W.E. Roth, Verlag der Studien aus dem Benedictiner- und Cistercienser-Orden, Brünn 1884, vol. 3, c.20-28, p.74). 
Predica a gusto acerca del pecado original, a fin de que la lección sea también doctrina para ti y aprecies la pulcritud y la pureza, ya que el que ama la pureza de corazón, por la gracia de sus labios, tendrá al rey como amigo (Prv 22,11). A esta lección la Virgen responde humildemente: Escucharé de qué me habla el Señor mi Dios (Sal 84,9). Y esto acerca de la lección de "pureza y pulcritud".

Después de salir la Virgen de esta escuela por medio del parto, con justicia apareció a la luz de este mundo, entre las gentes, como una mujer hermosa, docta y sabia. Su corazón e inteligencia adornaba el cúmulo de sus virtudes con la más feliz hermosura, tanto en su aspecto externo como en su disposición cercana, tal como dice Ambrosio en el Sermone Nativitatis Virginis: "las virtudes que habia en su inteligencia y en el afecto de su corazón extraían su inimitable armonía, que, junto con la sabiduría de Dios, le servían a ella, creadora y custodia para su deleite; estas virtudes resplandecian fuera, en la superficie tanto de sus palabras como de sus actos. En verdad, merecidamente pueden los hombres glorificar al Señor y tomar para sí ejemplos de salvación”. Esto decía Ambrosio.

Entendamos el término original, puesto que es lícito pensar que la culpa es contraída con o sin pecado original. Sin embargo desde el momento en que ella es santificada en el útero, es necesario creer que recibe de forma infusa por un lado las habituales virtudes teologales por medio de la gracia santificante y por otro, otras muchas cosas en razón de un privilegio singular, de tal forma que aparece tan hermosa como decorosa a ojos de los hombres.

Se admiraban de su sabiduría y se decían unos a otros: "no ha nacido sobre la tierra una mujer igual en aspecto, en hermosura, en sabiduría, en sensatez de palabras" (Idt 11,19).

Esto es lo que había que decir sobre la primera parte de la consideración, es decir, sobre la primera escuela sagrada: la de la "maternidad propia de las entrañas" y sobre la primera lección que es la de la pureza y la pulcritud.

Acerca de la segunda escuela, en la que se habla del "celo propio (217 v.b) de los padres" y en la cual tuvo lugar la segunda lección, a saber: la de la santidad y la justicia, pensemos que, confiada la Virgen a la sola educación de sus padres, ellos mismos, de acuerdo con un solo corazón, a semejanza de un único maestro, le dictaban la siguiente lección: "Escucha hija, callando con reverencia pues por medio de ella tendrás acceso a la buena gracia" (Sir 32,9). "Escucha hija, y te irá bien" (Prv 34). "Vergüenza es para el padre y la madre tener un hijo indisciplinado. La hija insensata, les nace para su humillación. Sin embargo la hija prudente es la mejor dote para su marido, pues aquella que se comporta como una desvergonzada sume a su padre en el ultraje. La hija temeraria avergüenza al padre y al marido y no se verá despreciada por los impíos; Sin embargo será deshonrada por ambos" (Sir 22,3-5). 
Ergo filia virgo, posside sapientiam, quia auro melior est, et acquire prudentiam, quia melior est argento (Prov. 16, [16]) ${ }^{1}$. Hoc dicimus quia cor sapiens et intelligibile abstinebit se a peccatis, et in operibus iustitiae successus suos habebit (Eccli. 3, [32])2.

Qua audita lectione, Virgo, cum spiritu potius quam ore respondens, ait: Dominus erigit mane, mane erigit mihi aurem et audiam Dominum et parentes quasi magistrum. Et Dominus Deus aperuit mihi aurem, et ego vestrae disciplinae non contradico (Is. 2) ${ }^{3}$.

Et hoc de lectione "sanctitatis et iustitiae" et de secunda schola "parentalis sedulitatis", per quam parentalem scholam Beata Virgo ducta in templum tanta fulgebat sapientia Altissimi et Dei scientia, tu merito amicta sole videretur, dicente Bernarno in sermone: Signum magnum apparuit in celo". "Propter hoc -inquit- Maria sole perhibetur amicta, quia profundissimae et divinae sapientiae, ultra quam credere valeat, penetravit abyssum et, quantum sine personali unione creaturae conditio patitur, luci illi inaccessibili videtur immersa" ${ }^{5}$. Et luna sub pedibus eius ${ }^{6}$, id est, defectus corruptionis vel corruptio mentis et stultia eiusdem. Hoc ille tu tam formosa et tam nominata debeat a cunctis laudari, dicente sapiente ad propositum: Collaudabunt multi sapientiam eius, et usque in saeculum non delebitur (Eccli. 39, [12]).

Et hoc de $2^{\mathrm{a}}$ schola, sive de secunda parte et consideratione et lectione, quae erat (218 a) "sanctitatis et iustitiae", per quam probatur Virgine "audivisse firma attentione".

Circa tertiam scholam, quae erat "spiritalis radietatis", et tertiam lectionem, quae erat "claritatis et notitiae", est speculandum quod collata data Virgine in templo, soli Deo vivo dedicata, adfuit magister, scilicet Spiritus Sanctus, ut suam virginem discipulam plenissime imbueret et informaret, quam excitat et alloquitur per haec verba: Surge, amica mea, columba mea, formosa mea, et veni (Cant. 2, [10]), et audi verba et consilia (Ex. 18, [19]). Nam si susceperis sermones meos, et mandata mea absconderis, penes te: ut audiat sapientiam auris tua. Si sapientiam invocaveris, et inclinaveris cor tuum prudentiae; si quaesieris eam quasi pecuniam, et sicut thesauros effoderis illam: Tunc intelliges timorem Domini, et scientiam Dei invenies. Scientiam Dei dico, verbum Dei increatum, quia Deus Pater dat increatam sapientiam, et ex ore eius per aeternalem emanationem, prudentia et scientia (Prov. 2, [1-6]).

${ }^{1}$ Prv 16,16: "posside sapientiam quia auro melior est adquire prudentiam quia pretiosior est argento".

${ }^{2}$ Sir 3,32: "cor sapiens et intellegibile abstinebit se a peccatis et in operibus iustitiae successus habebit".

${ }^{3}$ Is $50,4-5$ " ${ }^{4}$ Dominus dedit mihi linguam eruditam ut sciam sustentare eum qui lassus est verbo erigit mane mane erigit mihi aurem ut audiam quasi magistratrum. ${ }^{5}$ Dominus Deus apreruit mihi aurem ego autem non contradico retrorsum non abii”.

${ }^{4}$ Apc 12,1 .

${ }^{5}$ Remite Albert G. Hauf al "texto del tratado con el original de S. Bernardo". «Iure ergo Maria sole perhibetur amicta, quae profundissimam divinae sapientiae, ultra quam credi valeat, penetravit abyssum, ut quantum sine personali unione creaturae condicio patitur, luci illi inaccessibili videatur immersa»". Sermo in dominica infra octauam assumptionis beatae Mariae Uirginis, Bernardi opera, ed. J. Leclercq et H.M. Rochais, Editiones Cistercienses, Romae, 1968, vol. 5, p. 264. Cf. Dominica infra octavam assumptionis B. V. Mariae sermo, PL 183,431. ${ }^{6}$ Apc 12,1 . 
Por tanto la hija virgen, "poseerá la sabiduría por que es mejor que el oro y prudencia porque es mejor que la plata" (Prv 16,16). Esto lo decimos porque "un corazón sabio e inteligente se abstiene de pecar y obtiene su éxito de las obras de justicia" (Sir 3,32).

Escuchada esta lección, la Virgen, más con el espíritu que con la boca, respondiendo dijo: "mañana tras mañana me despierta el Señor el oído para que escuche al Señor y a mis padres como maestros". Y "el Señor Dios me abrió el oído y yo no replico vuestra enseñanza" (Is 2).

Y esto es lo que había que decir sobre la lección de "santidad y justicia" y sobre la segunda escuela, la del "celo propio de los padres". Gracias a esta escuela paternal, la Santa Virgen, conducida al templo, brillaba con tanta sabiduría del Altísimo y ciencia de Dios que merecidamente parecía "vestida del sol", tal como dice Bernardo en su sermón: Una gran señal apareció en el cielo. "Por esto se dice que María estaba revestida del sol, porque penetró en el abismo de la más profunda y divina sabiduría, más allá de lo que se pueda creer. Además, puesto que fue una criatura que no mantuvo unión personal alguna, está como sumergida en una luz inaccesible". Y la luna bajo sus pies: es decir, el defecto de la corrupción, la corrupción de la mente y la misma falta de juicio. Esto es lo que dijo aquél, de modo que una mujer tan hermosa y renombrada debiera ser alabada por todos, tal como dice el sabio a este propósito: "Muchos ensalzarán su sabiduría y nunca se le olvidará" (Sir 39,12).

Y esto es lo que había que decir sobre la segunda escuela, es decir, sobre la segunda parte y consideración y sobre la segunda lección, que era (218 a) la de "santidad y justicia", a través de la cual se demuestra que la Virgen "escuchó con firme atención”.

Acerca de la tercera escuela, que era la del "esplendor espiritual", y de la tercera lección, que era la de "la claridad y el conocimiento" hay que pensar que, cuando la Virgen fue ofrecida y entregada en el templo y consagrada al único Dios vivo, estuvo presente allí el maestro, esto es, el Espíritu Santo, para instruir y formar como su discípula a la Virgen, a la cual exhortaba y arengaba por medio de estas palabras: Levántate amiga mía, paloma mía, hermosa mía y ven (Ct 2,10) y escucha mis palabras y consejos (Ex 18,19). Pues si acogieras mis palabras y guardaras dentro de ti mis mandamientos de modo que prestara atención tu oído a la sabiduría; si la invocaras e inclinaras tu corazón a la prudencia; si la buscaras como al dinero y cavaras tras ella como tras un tesoro, comprenderías entonces el temor del Señor y descubrirías el conocimiento de Dios. Digo "conocimiento de Dios", "verbo de Dios increado" porque Dios Padre da la sabiduría increada y de su boca, por emanación eterna, procede la prudencia y el conocimiento (Prv 2,1-6). 
Ad quae verba, Virgo humiliter et devote respondit: Ave Deus noster! Quia in toto corde meo exquisivi te, et in corde meo abscondi eloquia tua (Ps. 118, [10]), ideo mitte sapientiam de sede marnitudinis tuae, ut mecum sit (Sap. 9, $[10])^{1}$. Et hoc de lectione "claritatis et notitiae".

Quam spiritalem scholam exiens, Virgo, lumine spiritali et scientia repleta, sponso traditur praeparata, ad intra ornata sapientiae ut thalamus Dei Patris sapientiae virtutibus ad ornatus decentissime aptaretur, quod memorans actor De laudibus Virginis inquit: "Virgo os suum apperuit sapientiae (Prov., ultimo)2. Os, dico, scilicet sapientiae hauriendo per studium, quia, spiritu sapientiae dictante vel docente, non stultitiae vel vanitati aut scurrilitati suum affectu aperuit, sed divinae sapientiae et intellectum et spiritum ab intelligentia Scripturarum attinget sufficienter ad quod plenissime edocta maneret, quia non decebat ut vas caelestis sapientiae expers esse a sapientia”. Haec ille.

Ideo sibi competit illud sapientis prophetae de matre virgine dictum: Sapientia, scilicet Dei Patris per Spiritum Sanctum docentem et sapiens aedificantem, aedificavit sibi domum ${ }^{3}$, singularis virtutibus et plenissime scientiae aedificatam et ornatam.

Et sic clare et liquide patet qualiter Beata Virgo in triplici schola fuit reperta "sapiens et prudens, audiendo firma attentione".

Et hoc de tertia schola, scilicet, "spiritalis radietatis", et de tertia lectione quae est "claritatis et notitiae".

[I.4.I.6] Sequitur nunc ostendere qualiter Beata Virgo fuit reperta "sapiens et prudens" audita, "custodiendo interna retentione".

${ }^{1}$ Sap 9,10: "mitte illam de sanctis caelis tuis et mitte illam a sede magnitudinis tuae ut mecum sit et mecum laboret...".

${ }^{2}$ Prv 31,26: "PHE os suum aperuit sapientiae et lex clemantiae in lingua eius".

${ }^{3} \operatorname{Prv} 9,1$. 
A estas palabras, la Virgen respondió humilde y devotamente: Ave, Dios Nuestro porque de todo corazón te busqué y en mi corazón preservé tus palabras (Ps 118,10). Por ello, manda tu sabiduría desde el trono de tu grandeza, para que esté conmigo (Sap 9,10). Esto es lo que había que decir acerca de la lección sobre "la claridad y el conocimiento".

Al salir de esta escuela espiritual, la Virgen, con la luz del Espíritu, llena de conocimiento, es entregada al esposo bien dispuesta y adornada en su interior con la sabiduría, de forma que el tálamo quedara muy decentemente adornado con las virtudes de la sabiduría de Dios Padre, tal como, haciendo memoria, dijo el autor de De laudibus Virginis: "la Virgen "abrió su boca a la sabiduría" (Prov. último). Digo "boca", como si devorara la sabiduría por medio del estudio, ya que, manifestándolo o prescribiéndolo el Espíritu de la sabiduría, no abrió su cuerpo a la necedad, la vanidad o a la bufonería sino que por medio de la comprensión de las Escrituras alcanzó de forma suficiente el conocimiento y el espíritu de la sabiduría divina para que se mantuviese plenamente instruida a la perfección ya que no convenía que la vasija de celestial sabiduría se viera desprovista de la propia sabiduría." Esto es lo que dijo el autor de De laudibus Virginis.

Por ello le corresponde lo dicho por el sabio profeta sobre la maternidad virginal: la sabiduría, es decir, la que procede de Dios Padre por medio del Espíritu Santo que enseña y edifica al sabio, le construyó su casa, edificada y adornada con singulares virtudes y con un conocimiento completísimo.

Así, queda patente de forma clara y límpida cómo la Santa Virgen, en esta triple escuela, fue hallada "sabia y prudente, escuchando con firme atención". Y esto es lo que había que decir acerca de la tercera escuela, es decir, la del "esplendor espiritual", y acerca de la tercera lección que es la de "la claridad y el conocimiento".

[I.4.1.6] Se continúa ahora tratando de mostrar cómo la Santa Virgen fue hallada "sabia y prudente" y cómo escuchaba "custodiando con interna retención”. 
Tradita Virgo Beata sponso, cellam ingreditur, quasi magni studii et efficax secretarum, commemorans illud (Eccli. 20, [7]): Homo sapiens tacebit usque ad tempus; lascivus autem et imprudens non servabit tempus. Ideo omnia sibi revelata in mente conferens, et in corde vehementi impressione scribens, librum grandem divinorum secretorum, suam animam construxit, dicente Ambrosio super id verbum": Maria autem conservabat, etc, (Luc. 2, [54]): "Maria, non minus ore quam corpore pudica, secreta quae noverat nulli divulgabat, sed tacito corde scrutans, congruum tempus quo Deus vellet haec divulgari reverenter expectans et expectante cognoscit". Haec ille. Quare angelus veniens, librum non casum, sed omni sapientia lege et virtutis exaratum reperiens, Virginis animam inquit: Ave, gratia plena! Plena dico sapientia, quia quante et qualis fuit sapientia in ea et scientia, quis digne loquar? "Quid de Deo non sapiebat, in qua sapientia Dei latebat, et in cuius utero corpus sibi aptabatur? Christus, ut ait apostolus, Dei virtus et sapientia, et in eo sunt omnes thesauri sapientiae et scientiae absconditi, Christus in Maria. Igitur Dei virtus et sapientia, et omnes thesauri sapientiae sunt in Maria, tu notat Anselmus in Sermone Assumptionis ${ }^{2}$.

Quare ergo Job, cognoscens utilitatem Virginis de sua sapientia nobis adducenda, orabat, II [5,6], dicens: O Virgo! Utinam Deus loqueretur tecum, et aperiet labia sua tibi, tu ostenderet tibi secreta sapientiae, eo quod multiplex est lex eius ${ }^{3}$. Et Virgo humiliter respondit: Congratulamini mihi, quia optavi, et datus est mihi sensus; et invocavi, et venit in me spiritus sapientiae (Sap. 7, [7]).

Et claret qualiter beata Virgo fuit reperta "sapiens (218 v.a) et prudens", custodiendo sanctas revelationes "interna retentione", etc.

[I.4.I.7] Sequitur nunc ostendere qualiter beata Virgo fuit reperta "sapiens et prudens" impartiendo et communicando suam doctrinam, "firma devotione vel superna affectione". Dato, igitur, tempore partus, sicut erat duplici sapientia plena, sic duplicem sapientiam mundo communicavit, vel impartita est in veram salutem humani generis redundantem.

1 "discamus sanctae uirginis in omnibus castitatem, quae non minus ore pudica quam corpore argumenta fidei conferebat in corde.". Expositio euangelii secundum Lucam, en Opera, CCSL 14, ed. de M. Adriaen, Brepols, Turnholti 1957, 57. Cf. Expositio Evangelii Secundum Lucam libri X comprehensa, II, 54, PL 15, 1572; Cf. Sant'Ambrogio, Opere esegetiche, XI, 1, ed. G. Coppa, Biblioteca Ambrosiana - Città Nuova, Milano - Roma 1978.

2 "Christus est, ait Apostolus, Dei virtus, et Dei sapientia (I Cor. 1, 24) : et In eo sunt omnes thesoiuri sapientiae et scientiae absconditi (Coloss. 2, 3), Christum autem in Maria. Ergo Dei virtus et Dei sapientia, et omnes thesauri sapientiae et scientiae in Maria”. Homilia IX In evangelium secundum Lucam, PL 158, 648-649.

${ }^{3}$ Iob 11,5-6: "5atque utinam Deus loqueretur tecum et aperiret labia sua tibi ${ }^{6}$ ut ostenderet tibi secreta sapoentiae et quod multiplex esset lex eius et intellegeres quod multo minora exigaris a Deo quam meretur iniquitas tua". 
La Virgen María, entregada al Esposo, entra en el templo como queriendo obtener un gran conocimiento de los misterios ${ }^{1} \mathrm{y}$ recuerda entonces aquello que se dice en Sir 20,7: El hombre sabio callará hasta el momento oportuno. Sin embargo, el fanfarrón y el necio no saben guardar su vez. Por ello, juntando en su mente todas las cosas que le fueron reveladas, grabándolas en su corazón con vehemente impresión, hacía de su alma un gran libro de los misterios divinos, tal y como dice Ambrosio por medio de este discurso: "“María sin embargo conservaba, etc." (Lc 2,54): María, mujer casta no menos en su boca que en su cuerpo, divulgaba misterios que nadie conocía. Escrutándolos con un corazón callado, esperaba con reverencia el tiempo propicio en que Dios quisiera que estas cosas fueran reveladas y al esperarlas, las terminó conociendo en profundidad?". Esto es lo que dijo Ambrosio. Por ello, el Ángel, cuando llegó, no encontró un libro roto, sino más bien un libro surcado por la sabiduría de toda ley y virtud y dijo: Ave María, llena de gracia. Digo más bien "llena de sabiduría" porque ¿quién hablará con justicia de cuánta y cuán grande fue la sabiduría y la ciencia que hubo en ella? Cristo, en quien están escondidos todos los tesoros de la sabiduría y la ciencia y que, tal como dijo el Apóstol, es virtud y sabiduría de Dios, ¿qué no conocía de Dios?, ¿en qué sabiduría de Dios estaba oculto?, ¿en el útero de quién preparaba su cuerpo? Cristo está en María. Así pues, la virtud y la sabiduría de Dios y todos los tesoros de la sabiduría están en María, tal y como lo advierte Anselmo en Sermone Assumptionis.

Por todo ello, Job, conociendo la ventaja con que contaba la Virgen gracias a su sabiduría, la cual nosotros debemos asumir, oraba diciendo: “ $\mathrm{OH}$ Virgen! Ójala Dios hablara contigo y te abriese sus labios para mostrarte los secretos de la sabiduría, aquello por lo que su ley tiene una interpretación múltiple” (Iob 11,5-6). La Virgen humildemente respondió así: "me felicitáis por que pedí y se me concedió la prudencia; supliqué y me vino el espiritu de Sabiduría" (Sap 7,7).

Así queda claro cómo la Virgen fue hallada "sabia y prudente", mientras custodiaba las santas revelaciones "con interna retención".

I.4.1.7. Se continúa ahora tratando de mostrar cómo la Santa Virgen fue hallada "sabia y prudente" mientras impartía y comunicaba su doctrina "con firme devoción y superior disposición". Llegado el momento del parto, puesto que estaba llena de una doble sabiduría, comunicó esa doble sabiduría al mundo, esto es, una sabiduría mostrada para redundar en la verdadera salvación del género humano.

${ }^{1}$ N.T. Traduzco efficax a partir de la derivación del verbo efficio. Los adjetivos en $a x$ tienen un significado general común de "insistencia en la acción verbal". De ahí: obteniendo repetidamente $\rightarrow$ queriendo obtener. 
Prima sapientia est Dei Verbum, ex Patre genitum et sibi omnino coaequale et consubstantiale, ad salutem nostrae redemptionis destinatum, secundum illud psalmum: Misit verbum suum, et sanavit eso, et eripuit, ${ }^{1}$ ect. Quod verbum appellatur sapientia, iuxta illud: Omnia in sapientia fecisti ${ }^{2}$. De qua sapientia ad praesens censetur supersedendi.

Secunda sapientia nobis communicata fuit vita et conversatio exemplum et Virginis doctrina, cuius doctrina debiles in fide roborantur, et infideles confunduntur, fundatores Ecclesiae amplius et amplius illuminantur, dicente Ieronimo in Tractatu de Passione: "Christus, ut omnia foedera pietatis commendaret, antiquum decretum quod de honorandis parentibus dictaverat servari voluit, et matrem adhuc volens esse ad consolationem Apostolorum, servavit superstitem, ut ex hiis quae ipsa ab eo viderat et audierat et in corde suo contulerat, senatus Apostolorum doceretur et evangelica doctrina firmaretur, et, cum tempus describendi Incarnationis eius adveniret, sufficienter omnia pro ut essent gesta, posset quaerentibus explicare"3. Haec ille.

Quare sapiens, loquens de doctrina et sapientia Virginis, ait: Sapientia laudabit animam suam, et in Domino honorabitur, et in medio populi sui gloriabitur, et in ecclesiis Altissimi aperiet os suum, et in conspectu virtutis illius gloriabitur (Eccli. 24, [1] $)^{4}$.

Et sic claret qualiter beata Virgo fuit reperta "sapiens et prudens impartiendo firma devotione et superna affectione".

Recolligendo igitur supra dicta, scilicet:

\begin{tabular}{|l|l|l|}
\hline \multirow{4}{*}{ "Virginis } & \multirow{2}{*}{ cordialem affectionem } & erga divinam sapientiam", \\
\cline { 2 - 2 } & internalem retentionem & \\
\cline { 2 - 2 } & maternalem intentionem & \\
\hline
\end{tabular}

possumus de ea affirmare congruenter atque congrua convenientia, quod ipsa "sapiens, prudens radiavit tu perlustrata sapientia", quae fuit prima pars minoris probanda.

${ }^{1}$ Ps $106,20$.

2 Ps 103, 24.

${ }^{3}$ Este tratado no aparece en la $P L$ (22-30), ni en otras ediciones como las Opera Homiletica, ed. G. Morin, CC 78, Brepols, Turnholti 1968.

${ }^{4}$ Sir 24,1-2. 
La primera sabiduría es la Palabra de Dios, que procede del padre y es igual y consustancial a Él en todo y que está destinada a la salvación de nuestra redención, según aquello que dice el Salmo: envió su palabra, los salvó y los arrebató de la fosa, etc. Esta palabra es invocada por la sabiduría, cuando se dice aquello de: "todas las cosas las has hecho con sabiduría". Con esta sabiduría son juzgados hasta el presente aquellos que han de estar sentados en lo alto.

La segunda sabiduría que se nos comunicó fue la vida y las palabras de la Virgen como ejemplo y doctrina. Gracias a su doctrina, los débiles son robustecidos en la fe, los infieles son confundidos y los fundadores de la Iglesia son iluminados cada vez más ampliamente, tal como dice Jerónimo en su Tractatu de Passione: "Puesto que hacía valer todas las alianzas de piedad, Cristo quiso que se conservara el antiguo decreto que había dictado acerca de la honra hacia los padres. Queriendo pues que su madre quedara aún para el consuelo de los Apóstoles, la conservó como testigo, para que a partir de todo aquello que de Él había visto y oído y que ella había reunido en su corazón, fuera instruido el senado de los Apóstoles, fuera confirmada la doctrina del Evangelio y, llegado el momento de exponer su encarnación, pudiera explicar suficientemente a quienes preguntaran, todo lo que había sucedido". Esto dijo Jerónimo.

Por ello, el sabio cuando hablaba de la doctrina y la sabiduría de la Virgen, decía: la Sabiduría elogiará su propia alma, se cubrirá de honor en el Señor, se gloriará en medio de su pueblo, en la asamblea del Altísimo abrirá su boca $y$ en presencia de su poder se gloriará (Sir 24,1).

Así queda claro cómo la Santa Virgen fue hallada "sabia y prudente" mientras impartía su doctrina "con firme devoción y superior disposición".

Recogiendo, así pues, lo dicho más arriba con respecto a la divina sabiduría, a saber...

\begin{tabular}{|c|c|}
\hline La cordial afección & \\
\hline La interna retención & \\
La maternal intención & de la virgen \\
\hline
\end{tabular}

...también podemos convenientemente afirmar acerca de ella cosas apropiadas y adecuadas ya que ella misma "brilló prudente y sabia como santificada por su sabiduría", lo cual constituye la primera parte de la premisa menor que había de ser demostrada. 
Ecce, si bene percipies, videbis in ista probatione (218 v.b) primi membri minoris, circa primo, quomodo dilatatur per quamdam distinctionem de sapientia et prudentia trimembrem, cuius quodlibet membrum est sufficienter probatum, et per quamdam applicationis subdivisionem de schola triplici, cum triplici ingenio et triplici lectione.

Secundo, videbis, qualiter prima pars vitae beatae Virginis quae assignandae, a sua conceptione usque ad Christi nativitatem, isti parti minoris applicatur.

Tertio, videbis quomodo nulla auctoritas est hic quae mentionem faciat de "corona", quoniam non est opus, eo quod hic probatur propositio ubi subiectum maioris praedicatur de medio, quod est subiectum de quo est sermo. Et ideo praedicatum maioris non ingreditur propositionem istam, quare non requiritur concordantiam principalioris partis thematis.

Nota tamen, quod si reperiretur aliqua auctoritas ubi reperiretur "corona", et illa possit expresse applicari Virgini probans ipsam Virginem esse sapientem, multum decoraret sermonem si adduceretur in istam prosecutionem minoris, quoniam et probaret propositionem et faceret concorditer ad themam. Verbi gratia, de ista auctoritate: Loquere maior natu; primum verbum diligenti scientiam (sic) et sapientia ut laetaris propter illos et ornamentum gratiae accipies coronam (Eccli. 32, [3]). Ista auctoritas potest applicari ultimae parti istius partis minoris probatae ubi dicitur quod Beata Virgo fuit visa sapiens per maternalem impartitionem, impartiendo scientiam et sapientiam quam noverat, in dictis scholis exponendo eam. Sic Dominus Altissimus, cognoscens Virginem propter suam plenitudinem scientiae deberet alios docere et primatum quasi doctrinae vel quasi doctorem tenere, inquit Virgini: Tu maior natu loquere, quoniam primum verbum debetur diligenti scientiam. Et hoc tibi committo: ut laeteris propter illos, scilicet discipulos, quos informabis scientia et doctrina. Et exponit sibi quae laetitia erit illa, dicens: Accipies ornamentum gratiae., scilicet "coronam I.

Quamquam hoc facere sit plenitudo sermonis, tamen est supereroganter factum, et durum sive grave, propter auctoritatum paucitatem.

Et hoc de modo probandi et dilatandi aliquam partem minoris per distinctionem.

${ }^{1}$ Sir 32,3-4: "3 ut laeteris propter illos et otnamentum gratiae accipias coronam et dignationem consequaris conrogationis ${ }^{4}$ loquere maior natu decet enim te". 
Ahora bien, si se presta atención, en esa comprobación (218 v.b) del primer miembro de la premisa menor, se ve en primer lugar de qué modo puede ser ampliada ésta por medio de cierta distinción trimembre -cuyo miembro quodlibético quedó suficientemente probado- que trate sobre la sabiduría y la prudencia, y por medio de una cierta subdivisión en torno a la aplicación de las tres escuelas, con las tres disposiciones y las tres lecciones.

En segundo lugar, se ve de qué modo la primera parte de la vida de santa María -la cual ha de ser imitada- desde su concepción hasta el nacimiento de Cristo, puede ser aplicada a esta parte de la premisa menor.

En tercer lugar, se ve que puesto que no es necesario, no hay ninguna autoridad tal que haga mención de "corona" ya que esta proposición puede ser demostrada cuando el sujeto de la premisa menor se predica a partir del medio, dado que éste es el sujeto sobre el cual trata el sermón. Por ello, el predicado de la premisa mayor no entra en esta proposición ya que no se requiere la concordancia de la parte principal del tema.

Debemos darnos cuenta, sin embargo, de que en el caso de que encontráramos alguna autoridad donde se hallase "corona" y ésta pudiera aplicarse expresamente a la Virgen probando que ella misma fue sabia, podría adornarse mejor el sermón acompañando a la premisa menor, ya que serviría para probar la proposición y concordaría con el tema. Veamos por ejemplo la siguiente autoridad: "Habla anciano; pues el que aprecia el conocimiento tiene la primera palabra y la sabiduría es útil para que te alegres por causa de ellos y recibas la corona como adorno de la gracia". (Sir 32,3). Esta autoridad puede aplicarse a la última parte probada de la parte de la premisa menor donde se dice que la Santa Virgen fue hallada sabia por su dedicación maternal, ya que impartía el conocimiento y la sabiduría que había conocido, exponiéndola en las citadas escuelas. Así, Dios Altísimo, sabiendo que la Virgen, por la plenitud de su conocimiento, debía enseñar a los demás y que tenía la primacía, por así decir, de la doctrina como doctora de la misma, le dijo: "Habla anciana, puesto que el que aprecia el conocimiento tiene la primera palabra. Esto es lo que te prometo: que te alegrarás por causa de ellos, es decir, de los discípulos, a los cuales formarás con tu conocimiento y tu doctrina." Y puso de manifiesto que ella era la misma alegría diciendo: "recibirás el adorno de la gracia," es decir "la corona".

Aunque proceder de este modo constituya el culmen del sermón, sin embargo se trata de algo excesivo, pesado y áspero para el oído, debido a la escasez de autoridades. Esto es lo que había que decir sobre el modo de probar y ampliar por distinción alguna parte de la premisa menor. 


\section{[I.4.I.8] Quomodo dilatatur per divisionem aliqua pars minoris}

Ostenso quomodo dilatatur minor per distinctionem, sequitur nunc ostendere qualiter dilatatur per divisionem aliqua pars minoris.

Ad modum exemplum sumatur secunda pars tacti minoris, quae fuit: quod Virgo gloriosa "propaginibus abundavit ut circumdata affluentia"; pro cuius (219 a) partis probatione, occurrit mihi illa auctoritas, Eccli. 24, [26]: Transite ad me, omnes qui concupiscitis me, et a generationibus meis adimplemini; spiritus meus super mel dulcis, et haereditas mea super mel et favum.

In qua auctoritate, si iuxta scientiam Virginis velimus contemplari, reperiemus in eadem tria

Primo: "Amorosam invitationem affectus declarativam".

Secundo: "Copiosam satisfactionem desiderium impletivam".

Tertio: "Saporosam recreationem amens delectativam".

\begin{tabular}{|c|c|c|}
\hline Primum & \multirow{3}{*}{ patet } & cum dicitur: Transite ad me, omnes qui concupiscitis me. \\
\hline Secundum & & cum dicitur: A generationibus meis adimplemini. \\
\hline Tertium & & $\begin{array}{l}\text { cum dicitur: Spiritus meus super mel dulcis, et haereditas mea } \\
\text { sicut mel et favum, etc. }\end{array}$ \\
\hline
\end{tabular}

Dixi, primo, quod in praedicta auctoritate reperiemus "amorosam invitationem affectus", scilicet ipsius matris declarationem, cum dicitur in praelibata auctoritate: Transite ad me, omnes qui concupiscitis me, etc. Pro cuius partis declaratione est notandum quod instituta Virgine per conceptum et partum vera perfectaque Matre Dei, incepit cuiuslibet hominis status, de summis miseriis et imperfectionibus ad magnas prosperitates et multiplicia clamare amorose, et affectuossissime invitare, dicendo: Transite ad me, etc. 
[I.4.1.8] Sobre cómo ampliar por división alguna parte de la premisa menor

Acabo de mostrar cómo se amplía la premisa menor por distinción y ahora mostraré como se amplía por división alguna parte de la premisa menor.

Se aporta a modo de ejemplo la segunda parte de la premisa menor ya tratada, la cual habla de la gloriosa Virgen cuya "descendencia fue abundante como rodeada de generosidad". Para la (219 a) comprobación de esta parte, me viene a la cabeza aquella autoridad de Si 24, 26: "Venid a mi todos los que me deseáis y hartaos de mis productos, que mi espíritu es más dulce que la miel y mi heredad mejor que el panal de miel".

Si quisiéramos examinar de cerca el conocimiento de la Virgen, en esta autoridad encontraríamos precisamente tres cosas:

En primer lugar: "una amorosa invitación que nos declara su afecto".

En segundo lugar: "una abundante satisfacción que sacia el deseo".

En tercer lugar: "una sabrosa recreación que pone freno a lo insensato".

\begin{tabular}{|l|l|l|}
\hline Lo primero & \multirow{4}{*}{ queda pegundo } & cuando se dice: "Venid a mi todos los que me deseáis". \\
\cline { 1 - 1 } Lo tercero & & cuando se dice: "hartaos de mis productos". \\
\cline { 3 - 3 } & & $\begin{array}{l}\text { cuando se dice: "mi espíritu es más dulce que la miel y mi } \\
\text { heredad mejor que el panal de miel". }\end{array}$ \\
\hline
\end{tabular}

En la autoridad anteriormente citada encontramos, en primer lugar, "una amorosa invitación que nos declara su afecto" -es decir, una declaración de la propia madre-, cuando se dice: "Venid a mi todos los que me deseáis". Para la declaración de esta parte, hay que señalar que la Virgen, dispuesta por medio de la concepción y el parto como verdadera y perfecta Madre de Dios, comenzó a llamar con amor a cualquier hombre cuya situación fuera de absoluta miseria e imperfección y a invitarlo con todo afecto a que alcanzara la mayor prosperidad y riqueza. Todo ello diciendo: "Venid a mi... etc". 


\begin{tabular}{|c|c|c|}
\hline Primo & \multirow{6}{*}{ invitabat } & "Expoliatos gloria aeternitatis". \\
\hline Secundo & & "Devictos principe mortis". \\
\hline Tertio & & "Debiles ad salutem venire non potentes". \\
\hline Quarto & & "Malos propter earum malignitatem". \\
\hline Quinto & & "Maestos duriori tristitia". \\
\hline Sexto & & "Indigens auxilio ad gloriam". \\
\hline
\end{tabular}

\begin{tabular}{|l|l|l|}
\hline Primo & \multirow{4}{*}{ Secundo } & "Transite ad me, nitens grandiosae haereditatis". \\
\cline { 1 - 1 } Tertio & \multirow{4}{*}{ dicendo } & "Transite ad me, solidum vigorem tristi fortitudinem". \\
\cline { 1 - 1 } Quarto & "Transite ad me, et vos faciam caelum scandentes". \\
\cline { 1 - 1 } Quinto & & "Transite ad me, iustam et praelectam bonitatem". \\
\cline { 1 - 1 } Sexto & "Transite ad me, caelesti fluente laetitia". \\
\cline { 1 - 1 } & "Transite ad me, consecutam mansionem perpetuam" $(219 \mathrm{~b})$. \\
\hline
\end{tabular}

Quae omnia succinti sermone ponit Anselmus in Orationibus ad Virginem, dicendo:

"O Maria! Tu genus humanum aeternitatis gloria nudatum ${ }^{1}$, reduxisti. Per tuum virgineum partum, in pristinum statum.

${ }^{1}$ Tractatus De Conceptione B. Mariae Virginis, PL 159, 315 (incluida en la obra spuria de Anselmo). No figura en la edición S. Anselmi Cantuariensis Archiepiscopi Opera Omnia, ed. F. S. Schmitt, Seckau 1938 (v. I); Nelson, Edimbourg 1946 (v. II-III), 1949 (v. IV), 1951 (v. V), 1961 (v. VI). Posiblemente la autoría es del discípulo de Anselmo, Eadmer de Cantorbery (Pseudo-Anselmo), redactado en 1127 o 1128. Cf. L. GALOT, "L'Immaculée conception de Notre Dame”, en Maria, Etudes sur la Vierge, vol. VII, Beauchesme et Fils, Paris 1964, pp. 9-11. 


\begin{tabular}{|c|c|c|}
\hline En primer lugar & \multirow{6}{*}{ invitaba } & A los despojados de la gloria de la eternidad. \\
\hline En segundo lugar & & A los sometidos por el príncipe de la muerte. \\
\hline En tercer lugar & & A los débiles, no a los poderosos, a alcanzar la salvación. \\
\hline En cuarto lugar & & A los que son malvados por causa de sus maldad. \\
\hline En quinto lugar & & A los afligidos por la más dura tristeza. \\
\hline En sexto lugar & & $\begin{array}{l}\text { A los que están necesitados de ayuda para alcanzar la } \\
\text { gloria. }\end{array}$ \\
\hline
\end{tabular}

\begin{tabular}{|l|l|l|}
\hline & en primer lugar: & $\begin{array}{l}\text { "Venid a mi, que resplandezco por mi gloriosa } \\
\text { heredad". }\end{array}$ \\
\cline { 2 - 3 } Diciendo & en segundo lugar: & $\begin{array}{l}\text { "Venid a mi, los que estáis tristes, pues soy sólido } \\
\text { vigor y fortaleza". }\end{array}$ \\
\cline { 2 - 3 } & en tercer lugar: & "Venid a mi, y os haré ascender hasta el cielo". \\
\cline { 2 - 3 } & en cuarto lugar & $\begin{array}{l}\text { "Venid a mi, que soy bondad justa y elegida con } \\
\text { antelación" }\end{array}$ \\
\cline { 2 - 3 } & en quinto lugar: & "Venid a mi con la alegría que fluye desde cielo" \\
\cline { 2 - 3 } & en sexto lugar: & "Venid a mi, mansión perpetua" (219 b). \\
\hline
\end{tabular}

Todas estas cosas las expone, en un sucinto sermón, Anselmo, en Orationibus ad Virginem, cuando dice:

“;Oh María! Tú, por tu parto virginal, volviste a conducir al género humano

a su estado original,

a la gloria de la eternidad. 
Tu, rege inferni devicto, per mortem Filii tui principem mortis evertisti. Per te ad aeternam gloriam pervenimus. Per te, est si quid boni sumus. Tu, post Deum, summa et singularis consolatio nostra. Tu felix gloriatio nostra, quaesumus, esto in ipso beatitudinis regno susceptrix ac perpetua exultatio nostra". Haec ille. Ut pro auctoritatis concordantia Virginis "amorosa invitatione", occurrat id quod scribitur Iosue 22, 19: Transite ad terram, in qua tabernaculum Domini est. Et hoc de prima parte auctoritatis.

Hic applica primam partem vitae Virginis post partum Filii Dei, ubi poteris applicari et ad propositum, qualiter spirituali desiderio Virgo invitabat res conditas per Filium Iesum, ut eius nativitatem toti mundo, propalaret, scilicet: solem, stellas, reges, pastores, obstetrices, sacerdotes et omnia alia, ut quodam modo de Christi nativitate testimonium perhiberent. De Christi nativitate dimitto lectori prospicienti.

Dixi, secundo, quod in praedicta auctoritate reperiemus "copiosam, etc". Pro cuius declaratione nota quod congregata multitudine utriusque sexus generis humani per amorosam Virginis invitationem, ut dictum est, incepit Mater Virgo omnes visceraliter materno amore recolligere, ut eso sanctos et iustos pareret ad salutem; qui conceptus dicitur divini amoris et caritatis, et partus dicitur exemplum vitae et veritatis. Per eiusdem partum ipsa Virgo extitit multarum gratiarum mater:

\begin{tabular}{|l|l|}
\hline \multirow{4}{*}{ "Ipsa est mater } & Virginum, per Sponsi aeternam contemplationem. \\
\cline { 2 - 3 } & Apostolorum, per claram de caelo attestationem. \\
\cline { 2 - 3 } & Martyrum, per dolorosam mentis passionem. \\
\cline { 2 - 3 } & Confitentium, per rigidam carnis macerationem. \\
\cline { 2 - 3 } & Prophetarum, per infusam venturorum agnitionem". \\
\hline
\end{tabular}


Tú, sometido el rey del infierno, derribaste al príncipe de la muerte por medio de la muerte de tu Hijo. Por ti hemos llegado a la gloria eterna. Si en algo somos buenos es gracias a ti. Después de Dios, tú eres nuestro más grande y único consuelo. Nosotros te pedimos que tú, feliz gloria nuestra, seas, en este mismo reino de felicidad, la que con jubilo nos acoge". Esto es lo que dijo Anselmo. Para que la autoridad concuerde con la "amorosa invitación" de la Virgen, debe darse aquello que aparece escrito en Jos 22, 19: "Venid a la tierra en la cual está el tabernáculo del Señor". Esto es lo que había que decir sobre la primera parte de la autoridad

Se utiliza esta primera parte de la vida de la Virgen -después del parto del Niño Dios-, allí donde se pueda aplicar para el siguiente propósito: el de que la Virgen, con un deseo Espiritual y por medio del Niño Jesús, presentaba en ofrenda todas las cosas creadas para propagar el nacimiento de su hijo por todo el mundo. Ofrecía el sol, las estrellas, los reyes, los pastores, las parteras, los sacerdotes y todas las demás cosas, de modo que proporcionasen testimonio del nacimiento de Cristo. Dejo al lector que escudriñe con detenimiento el nacimiento de Cristo.

Dije, en segundo lugar, que en la autoridad anteriormente citada, encontramos "una abundante satisfacción que sacia el deseo". Para la declaración de esta autoridad, hay que darse cuenta de que la Virgen Madre, congregada una multitud de uno y otro sexo del género humano gracias -tal como queda dicho- a su amorosa invitación, comenzó a reunir a todos en sus entrañas, con amor de madre, para que estos, como santos y justos, quedaran sometidos a la salvación. Podemos decir que su concepción fue fruto del amor divino y de la caridad y que su parto fue un ejemplo de vida y de verdad. Por medio de su mismo parto, la propia Virgen se convirtió en madre de muchas gracias:

\begin{tabular}{|c|c|}
\hline \multirow{5}{*}{ Ella misma es madre... } & ...de las vírgenes, por la eterna contemplación del esposo. \\
\hline & ...de los Apóstoles, por el claro testimonio del cielo. \\
\hline & ... de los mártires, por la dolorosa pasión de su alma. \\
\hline & ... de los confesores, por la severa mortificación de su carne. \\
\hline & $\begin{array}{l}\ldots \text { de los profetas, por el conocimiento que le fue infundido, sobre } \\
\text { lo que ha de venir. }\end{array}$ \\
\hline
\end{tabular}


Et sic quibuscumque approbatis statibus, quorum exemplum et radix fuit Virgo. Et rogo si potes numerare stellas, et tunc enumerabis istius amorosae Matris generationem. Et voco ipsam Matrem amorosam, nam hos quos generavit suae genuit in caritate, et per caritatem (219 v.a) concepit, ardore caritatis Filium concipiendo inserenda sagitta electa ${ }^{1}$ est amor Christi, qui Mariae animae non tantum modo figitur, sed etiam pertransivit eam ut veniret usque ad nos, et de plenitudine eius omnes acciperemus ${ }^{2}$, et fieret omni mater caritatis et etiam mater pulchrae dilectionis ${ }^{3}$. Haec ille. Ut pro concordantia auctoritatis et suae copiosae generationis ducitur interrogative: Quis hunc fecit, scilicet, ut tot filii caritatis essent et dilectionis; an quis hoc operatus est? Et respondens Beata Virgo: Illa quae vocavit et invitavit generationes $a b$ exordio, id est, ab initio verae redemptione, id est, Incarnationis (Is. 41, [4]). Et ideo ex hoc omnes generationes non sine causa dicunt ipsam beatam (Lucae primo, [48]). Et hoc de $2^{a}$ parte auctoritatis.

Hic poteris applicare aliam partículam vitae Virginis a tempore reversionis de Aegypto, vel repertionis Filii in templo, usque ad mortem, exclusive; in quo tempore fuit cognita Beata Virgo testificatrix Christi et Mater gloriosa, ventura anuntians et caeteris, qui studenti relinquo prospicuo.

Dixi, tertio, quod in eadem auctoritate reperiemus eius "saporosam, etc". Pro quo notandum quod, data Christi passione, collegium Apostolorum suorum in fide titubavit, ut in eis non esset spiritus dulcoris, agnitionis fidei, scilicet, et spei. Sed in ista Mater Sanctissima numquam defuit spiritus suavis et mansuetus, scilicet firmissimae credulitatis et sanctae spei et pietatis, ex quo spiritu procedebant verba dulcia omnium audientium confortativa et ad fidem allectiva, iuxta illud Sapientis: Verbum dulce mitigat inimicos, et multiplicat amicos ${ }^{4}$. Quare verba oris sui sunt dulcia in faucibus, quotiescumque melliflua audientibus, saltim patet in Psalmo ${ }^{5}$.

${ }^{1}$ Podría referirse a Is 49,2 : "et posuit os meum quasi gladium acutum in umbra manus suae protexit me et posuit me sicut sagittam electam in faretra sua abscondit me". Cf. A. G. Hauf, p. 292.

${ }^{2}$ Io 1,16 : "Et de plenitudine eius nos omnes accepimus et gratiam pro gratia".

3 Sir 24,24: "ego mater pulchrae dilectionis et timoris et agnitionis et sanctae spei".

${ }^{4}$ Sir 6,5.

${ }^{5}$ Ps. 118,103: “(iuxta LXX) quam dulcia faucibus meis eloquia tua super mel ori meo". 
Y así sobre cualquiera de los estados que se quieran comprobar, cuyo ejemplo y raíz fue la Virgen. Me pregunto ahora si podrías contar las estrellas del cielo. En tal caso podrás contar también la descendencia de esta amorosa Madre. A ella misma la denomino amorosa Madre porque aquellos a los que engendró, los engendró para sí en el amor; gracias al amor (219 v.a) los concibió. Y cuando se anuncia con solemnidad al Hijo por medio del ardor de la caridad, sucede que podemos comparar el amor de Cristo con una flecha escogida a punto de clavarse, ya que no solo se hundió en el alma de María, sino que la atravesó por medio para llegar hasta nosotros, de modo que todos aceptáramos lo que viene de su plenitud y de forma que ella misma se convirtiese para todos en madre de la caridad y por tanto en madre del amor hermoso. Esto es lo que dijo aquel. Para poner en consonancia la autoridad y el copioso linaje de la Virgen, se plantea la siguiente pregunta: "¿Quién hizo esto, es decir, que hubiese tantos hijos de la caridad y del amor? ¿Quién hizo esto posible?" A lo cual la Virgen responde: "aquella que convocó y atrajo a las generaciones desde el comienzo, es decir, desde el inicio de la verdadera redención, de la Encarnación (Is 41, 4)". Y por esto todas las generaciones, no sin causa, la llamarán bienaventurada (Lc 1, 48). Y esto sobre la segunda parte de la autoridad.

Aquí podemos aplicar la otra parte de la vida de la Virgen: desde el tiempo de la vuelta de Egipto -es decir, desde que encontraron al Hijo en el templo- hasta su muerte, sin incluirla. En este tiempo la Santa Virgen fue reconocida como testigo de Cristo, como Madre gloriosa, mensajera de lo que ha de venir, etc... Dejo esto para un estudio más profundo.

Dije en tercer lugar que en la misma autoridad encontramos su "sabrosa recreación que pone freno a lo insensato". Para la declaración de esta autoridad hay que darse cuenta de que, tras consumarse la pasión de Cristo, la fe del colegio de sus Apóstoles se tambaleó, de forma que en ellos no había espíritu alguno de sabor dulce, de conocimiento de la fe y en conclusión, de esperanza. Pero en esta Santísima Madre nunca faltó un espíritu agradable, manso, un espíritu de la más firme credulidad, de santa esperanza y piedad. De este espíritu procedían las palabras más dulces y confortables oídas por nadie, palabras que mueven a la fe, tal como aquello que dijo el Sabio: "la palabra dulce mitiga a los enemigos y multiplica los amigos". Que las palabras de su boca resultan dulces en sus fauces, siempre melifluas para quien las oye, queda más o menos patente en el salmo. 
Hic applica aliud originale, probans Beatam Virginem verbis dulcibus in passione Christi multos ad fidem allicientem, et hoc doctrina particula auctoritatis.

Recolligens igitur praedicta pro ista parte, scilicet Beatae Virginis "invitationem amorosam", quae multos ad se congregavit "satisfactionem copiosam" (219 v.b), quam magnam progeniem adoptavit, ita quod quilibet apostolus et sanctus, verbis Virginis confortatus, potuit dicere per tunc: Quam dulcia faucibus meis eloquia tua, super mel ori meo, "recreationem saporosam", quia natos fide dulcoravit; possumus convenienter sustinere ex ista experiencia quod ipsa Virgo "propaginibus abundabit tu circumdata affluentia", quae fuit $2^{a}$ pars minoris.

Ecce vides qualiter sub ipsa $2^{\mathrm{a}}$ parte minoris fuit sermo prolongatus sumendo scilicet unam auctoritatem probationem, scilicet illam partem minoris; quae auctoritas fuit divisa in tres partes, et quaelibet pars fuit probata auctoritate et originali, et cuilibet applicata aliqua particula secundae partis vitae Beatae Virginis gloriosae. Et si hoc consideras, poteris cognoscere quomodo fit dilatatio sermonis per divisionem factam circa aliquam auctoritatem ductam per alicuius partis probationem.

[I.4.I.9] Sequitur nunc ostendere qualiter dilatatur sermo per auctoritatum cumulationem sub aliqua parte minoris

Ad cuius exemplum sumatur tertia pars minoris in ista forma: Dixi, tertio, quod Beata Virgo "super comissos vigilavit, tu affectata diligentia", quod sic probatur: Nos sumus oves et pecora Beatae Virgini commissa, ut in Psalmo: 
Aquí podemos aplicar otro original que sirva para probar que la Santa Virgen, por medio de dulces palabras, durante la pasión de Cristo, atrajo a muchos a la fe. Todo esto sobre la doctrina de cada una de las partes de la autoridad.

Recojamos ahora lo anteriormente dicho hasta esta parte:

"La amorosa invitación" de la Santa Virgen que hizo que muchos se congregaran junto a ella.

"Una abundante satisfacción" que adoptó bajo la forma de una gran descendencia, de modo que cualquier Apóstol o santo, confortado con las palabras de la Virgen, pudo decir entonces:

"Qué dulces son tus palabras para mis fauces, más que la miel para mi boca". "Una sabrosa recreación" (219 v.b), porque sirvió para endulzar a los nacidos en la fe.

A partir de esta experiencia podemos sostener de forma conveniente que la misma Virgen tuvo una "descendencia abundante como rodeada de generosidad", lo cual constituye la segunda parte de la menor.

Aquí se puede ver cómo se prolonga el sermón bajo esta segunda parte de la menor, tomando como prueba una sola autoridad, la que corresponde a esta parte de la premisa. Esta autoridad fue dividida en tres partes. Cada una de las partes fue probada con una autoridad y un original y a cada una de ellas les fue aplicada una parte del segundo periodo de la vida de la gloriosa Santa Virgen.

Si se considera esto con atención, sabrás de qué modo se hace una ampliación por medio de una división hecha a alguna autoridad traída como prueba de alguna de las partes.

[I.4.1.9] Continuamos ahora mostrando cómo se amplia el sermón por medio de la acumulación de autoridades bajo alguna parte de la menor

Como ejemplo de esto tomamos la tercera parte de la menor de la forma que explico a continuación: en tercer lugar dije que la Santa Virgen "vigiló a los que le fueron confiados como movida por la diligencia", lo cual puede probarse así: nosotros somos las ovejas y los corderos confiados a la Santa Virgen, tal como dice el Salmo: 
Nos autem populus eius et oves pascuae eius ${ }^{1}$. Et sicut nos modo sumus oves, ita et per passionem Filii sui grex discipulorum et Apostolorum fuit temeritudine commissus, quo tempore lupi rapaces, iudaei, et bestiae silvestres, gentiles, mactare et perdere affectabant christianos velut oves pro quo vigore pervertere a fide; super quibus Beata Virgo vigilavit cum magna comitiva angelorum custodientium et associantium Virginem, bellantium contra spirituales nequitias gregemque defendendam, armata gladio verbi Domini contra ignorantiae noctis caecitatem, in tantum quod timor erat vsibilibus et invisibilibus inimicis, ut acies ordinata castrorum"; dicente Bernardo in Sermone: "An non horruerunt principes tenebrarum quando viderunt praeter morem instructam omni armatura fortium contra se progredi feminam fortem ad bella doctissimam, cuius ensis supra femur suum propter timores nocturnos ${ }^{3}$, et in circuitu eius acies valida spiritualium virtutum suo se invicem ordine defendentes, sed et innumerabilium beatorum spirituum militiam ad ministerium tanti principis delegatam fuisse? (220 a) Nullatenus ambigemus"4. Haec ille. Cum quo exercitu vigilabat, dicens: Ego dormio, et cor meum vigilat (Cant. 5, [2]) Quasi dicat Virgo: et si reperior ut femina puella propter nimiam mansuetudinem dormiens, cor meum vigilat supra mihi commissum gregem. O Domine Deus, quos tu dedisti mihi, non perdidi ex eis quemquam! ${ }^{5}$

Quam sollicitudinem et vigilantiam tenut usque ad ultimum vitae suae, in quo et Apostolos sibi commissos voluit personaliter videre.

Ex quibus patet luculenter in Virginis Gloriosae, quo ad quamlibet suae vitae partem experientia, quod ipsa "supra commisso vigilavit ut affectata diligentia", quae fuit tertia pars minoris.

Ecce vides exemplum quomodo in ista tertia parte fit dilatatio sermonis solum per auctoritatum cumulationem, coniugendo originale auctoritatibus, et igitur qualiter poteris et tu prolongare. Et si velles et posses adducere illam auctoritatem Ieremiae, I ${ }^{\circ}$ capitulo, 11: Quid tu vides, Ieremia? Respondit: Virgam viligantem ego video. Et expone eam per modum figurae, declarando quomodo Virgo Maria vigilavit, et sic faciendo modo excites propositum et dilatares sermonem per auctoritates.

Probata igitur utraque minoris parte concludatur thema; totum antecedens informa, resumendo sic:

1 Ps 99,3 .

${ }^{2} \mathrm{Ct}$ 6, 3.9: "3 pulchra es amica mea suavis et decora sicut Hierusalem terribilis ut castrorum acies ordinata... ${ }^{9}$ quae est ista quae progreditur quasi aurora consurgens pulchra ut luna electa ut sol terribilis ut acies ordinata".

${ }^{3} \mathrm{Ct} \mathrm{3,8.}$

${ }^{4}$ Migne niega la autoría del sermón a Bernardo. Sermo Panegyricus ad Beatam Virginem Deiparam, PL 184, 1013: "Non est Bernardi, nec reperitur inter ejus Sermones in vetustis editis, nec in manuscriptis nisi admodum paucis aut melioris notae: atque ideo in hunc locum nunc primum rejectus est. Esse Ekkeberti abbatis passim testatur Richardus a Sancto-Laurentio, qui ante annos quadringentos scripsit, et plagulas ex illa precatione decerpens, Ekkeberto tribuit, ut Theophilus Raynaudus in sua Api Gallica pridem observavit. Is est Ecbertus abbas Schonangiensis, cujus Sermones adversus Catharos exstant in tomo XII Bibliothecae Patrum editionis Coloniensis".

5 Io 18,9 . 
"Somos su pueblo y ovejas de su rebaño". Del mismo modo que nosotros somos ovejas, así también, por medio de la pasión de su Hijo, la grey de los discípulos y los Apóstoles le fue confiada a ella, temerosa, en un tiempo en el que unos lobos rapaces, los judíos, y unas bestias silvestres, los gentiles, trataban de matar y sacrificar a los cristianos como si fuesen ovejas, con una fuerza tal que les apeara de su fe. Precisamente sobre estos mantuvo su vigilancia la Santa Virgen, con una gran comitiva de ángeles que custodiaban y se asociaban a la Virgen y que hacían la guerra contra las indolencias espirituales. Ella, como un ejército dispuesto en el campamento para la batalla, luchó por defender a su grey, armada con la espada de la Palabra de Dios contra la ignorancia y la ceguera de la noche, en un momento en el que el miedo era visible y los enemigos invisibles. Dice Bernardo en su sermón: "¿Acaso no se horrorizaron los príncipes de las tinieblas cuando vieron que avanzaba hacia ellos una mujer fuerte, muy instruida para las batallas, poniendo por delante un carácter equipado con la completa armadura de los fuertes y cuya espada permanece sobre su muslo por causa de los temores de la noche; cuando, defendiéndose a su vez ellos a su manera, vieron en su territorio a un robusto ejercito de virtudes espirituales; cuando una milicia de innumerables santos espiritus fue dedicada a la labor de hacer frente a tanto príncipe? (220 a) Esto es algo que no se puede discutir". Esto dijo Bernardo. Con este ejército vigilaba diciendo: "Yo duermo, pero mi corazón permanece en vela" (Cant 5, 2). Es como si la Virgen dijera: "aunque alguien me encontrara como una niña que con gran dulzura duerme, sin embargo mi corazón vigila a la grey que me fue confiada. ¡Oh Señor Dios! ¡No perdí a ninguno de aquellos que me diste!"”

Esta solicitud y vigilancia la mantuvo hasta el último momento de su vida, en el cual quiso ver también a los Apóstoles, los cuales le habían sido confiados.

A partir de todo esto queda muy bien expuesto, en la experiencia de la Gloriosa Virgen, que ella misma, durante toda su vida "vigiló a los que le fueron confiados como movida por la diligencia". Esta fue la tercera parte de la menor.

A continuación tenemos un ejemplo de cómo en esta tercera parte puede ampliarse el sermón únicamente por acumulación de autoridades, mediante la adición de un original a las mismas. Esto constituye por tanto un ejemplo de cómo tú mismo puedes prolongarlo. Si se quiere, también se puede aducir como autoridad aquella de Jer. 1, 2: ¿Qué ves, Jeremías?” Él respondió: "Veo una rama que vigila". Se expone esta autoridad por medio de una figura, declarando el modo en que la Virgen María vigilaba. De esta manera se pone al descubierto tu propósito y se amplía el sermón con las autoridades.

Probada una y otra parte de la menor se concluye el tema y se organiza entonces todo lo dicho con anterioridad mediante un resumen de este tipo: 


\begin{tabular}{|l|l|l|}
\hline \multirow{2}{*}{$\begin{array}{l}\text { "Quaelibet } \\
\text { creatura }\end{array}$} & Quae superno infuso numine est compta sapientia & \\
\cline { 2 - 3 } & Quae lato copioso germine est fulta affluentia & $\begin{array}{l}\text { Corona ornatur in culmine } \\
\text { capitis decentia". }\end{array}$ \\
\cline { 2 - 3 } & Quae super gratioso agmine est vigil diligentia & \\
\hline
\end{tabular}

Sed, ut sufficienter probatum extitit, Beata Virgo Maria in toto suae vitae decursu

\begin{tabular}{|l|l|l|}
\hline "Sapiens, prudens radiavit & \multirow{4}{*}{ ut } & Perlustrata sapientia. \\
\cline { 1 - 1 } Propaginibus abundavit & & Circumdata affluentia. \\
Super commissos vigilavit & & Affectata diligentia". \\
\hline
\end{tabular}

Igitur: "legitime suum caput adornavit coronae excellentiae", quae fuerunt verba nostri thematis ad honorem Beatae Virginis nobis praesentata. Et hoc de introductione per syllogismum vel in forma syllogistica, etc. 


\begin{tabular}{|c|c|c|}
\hline \multirow{3}{*}{$\begin{array}{l}\text { Cualquier } \\
\text { criatura }\end{array}$} & $\begin{array}{l}\text {...que, recibida la inspiración suprema, queda } \\
\text { adornada con la sabiduría... }\end{array}$ & \multirow{3}{*}{$\begin{array}{l}\text { Ha de ser honrada con la } \\
\text { corona en lo más alto de } \\
\text { la cabeza bien por gracia } \\
\text { bien por plenitud. }\end{array}$} \\
\hline & $\begin{array}{l}\text {...que, tras recibir amplio y copioso germen, está } \\
\text { sostenida en la abundancia... }\end{array}$ & \\
\hline & $\begin{array}{l}\text {... que mantiene una vigilancia diligente sobre } \\
\text { una multitud amada... }\end{array}$ & \\
\hline
\end{tabular}

Sin embargo, para que todo quede suficientemente probado, hay que decir que la Santa Virgen María en el transcurso de su toda su vida...

\begin{tabular}{|l|l|l|}
\hline Brilló sabia y prudente & \multirow{4}{*}{ como } & santificada por la sabiduría. \\
Tuvo una descendencia abundante & & rodeada de generosidad. \\
Vigiló a los que le fueron confiados & & movida por la diligencia \\
\hline
\end{tabular}

Por todo ello "convenientemente adornó su cabeza con la excelencia de la corona". Estas han sido las palabras del tema que nosotros hemos presentado en honor de la Santa Virgen. Esto es lo que había que decir acerca de la introducción por silogismo o en forma silogística. 